\title{
The Magnitude, Destinations, and Determinants of Mathematics and Science Teacher Turnover
}

By

Richard M. Ingersoll

and

Henry May

GRE

The Consortium for Policy Research in Education includes:

University of Pennsylvania Teachers College Columbia University Harvard University Stanford University University of Michigan University of Wisconsin-Madison Northwestern University 


\section{About the Consortium for Policy Research in Education (CPRE)}

Established in 1985, CPRE unites researchers from seven of the nation's leading research institutions in efforts to improve elementary and secondary education through practical research on policy, finance, school reform, and school governance. CPRE studies alternative approaches to education reform to determine how state and local policies can promote student learning. The Consortium's member institutions are the University of Pennsylvania, Teachers College-Columbia University, Harvard University, Stanford University, the University of Michigan, University of Wisconsin-Madison, and Northwestern University.

Most recently, CPRE has opened two major centers-the Center on Continuous Instructional Improvement, a center engaged in research and development on tools, processes, and policies intended to promote the continuous improvement of instructional practice; and the Strategic Management of Human Capital in Public Education, a center focused on improving the quality of classroom instruction and student outcomes in $\mathrm{K}-12$ classrooms by radically improving the strategic management of teaching and instructional leadership talent (human capital) in large, public school districts.

To learn more about CPRE and our new research centers, visit the following web sites:

www.cpre.org (CPRE's main web site)

www.ccii-cpre.org (CCII)

www.smhc-cpre.org (SMHC)

Want to learn more about new and upcoming CPRE publications, project research findings, or where CPRE researchers are presenting? Visit our website at http://www.cpre.org or sign up for our e-newsletter, In-Sites, at insites@gse.upenn.edu.

\section{CPRE Research Report Series}

Research Reports are issued by CPRE to facilitate the exchange of ideas among policymakers, practitioners, and researchers who share an interest in education policy. The views expressed in the reports are those of individual authors, and not necessarily shared by CPRE or its institutional partners. 


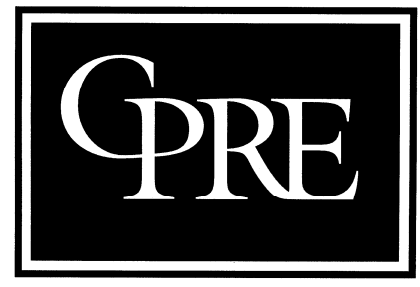

\title{
Consortium for Policy Research in Education
}

University of Pennsylvania | Teachers College | Harvard University | Stanford University | University of Michigan | University of WisconsinMadison | Northwestern University

\section{The Magnitude, Destinations, and Determinants of Mathematics and Science Teacher Turnover}

\author{
By \\ Richard M. Ingersoll \\ and \\ Henry May
}

CPRE Research Report \# RR-66

This research was supported by a grant (\# 0455744) from the Teacher Professional Continuum Program of the National Science Foundation. Opinions in this paper reflect those of the authors and do not necessarily reflect those of the granting agency, the Consortium for Policy Research in Education or its research partners. David Perda and Elizabeth Merrill provided valuable assistance. Findings from this paper were presented at the 2010 annual meeting of the Society for Research on Educational Effectiveness, in Washington, DC. Thanks are due to Michael Strong and Ed Fuller for helpful comments on an earlier draft.

October, 2010 


\section{Table of Contents}

\begin{tabular}{|l|r|}
\hline Abstract & 1 \\
\hline Introduction & 2 \\
\hline The Importance of Employee Turnover & 3 \\
\hline The Importance of Teacher Turnover & 6 \\
\hline Research on Mathematics and Science Teacher Turnover & 7 \\
\hline The Study & 11 \\
\hline Data and Methods & 11 \\
\hline Data & 12 \\
\hline Measures and Methods & 21 \\
\hline Results & 21 \\
\hline The Magnitude of Mathematics and Science Teacher Turnover & 23 \\
\hline The Destinations of Mathematics and Science Teacher Turnover & 26 \\
\hline The Determinants of Mathematics and Science Teacher Turnover & 29 \\
\hline Individual, School, and Organizational Predictors of Turnover & 40 \\
\hline Conclusions and Implications & 41 \\
\hline Magnitude & 42 \\
\hline Destinations & 43 \\
\hline Determinants & 46 \\
\hline Policy Implications & 49 \\
\hline References & \\
\hline Endnotes & \\
\hline
\end{tabular}




\section{Figures}

\begin{tabular}{|l|r|}
\hline $\begin{array}{l}\text { Figure 1. An Organizational Perspective on the Causes and Consequences of } \\
\text { Mathematics/Science School Staffing Problems }\end{array}$ & 9 \\
\hline $\begin{array}{l}\text { Figure 2: Number of Math/Science Teachers Who Moved To and From } \\
\text { Particular Types of Public Schools (2004-2005) }\end{array}$ & 26 \\
\hline $\begin{array}{l}\text { Figure 3. Predicted Public School Teacher Turnover Rates, by School } \\
\text { Organizational Condition Percentiles, by Field (2004-2005) }\end{array}$ & 40 \\
\hline
\end{tabular}

\section{Tables}

\begin{tabular}{|c|c|}
\hline Table 1. Definitions of Measures Utilized in the Regression Analysis & 16 \\
\hline $\begin{array}{l}\text { Table 2. Descriptive Statistics for Independent Variables Utilized in } \\
\text { Regression Analysis }\end{array}$ & 17 \\
\hline $\begin{array}{l}\text { Table 3. Percent Annual Public School Teacher Migration and Attrition, by } \\
\text { Field, and by Year. }\end{array}$ & 23 \\
\hline $\begin{array}{l}\text { Table 4. Percent Public School Teacher Migration and Attrition, by New } \\
\text { Schools of Movers and by Main Occupational Status of Leavers, and by } \\
\text { Field (2004-05) }\end{array}$ & 24 \\
\hline $\begin{array}{l}\text { Table 5. Of Public School Teachers Who Moved to Other Schools, Percent } \\
\text { Reporting Various Categories of Reasons Were Very or Extremely } \\
\text { Important to Decision, by Field (2004-05) }\end{array}$ & 27 \\
\hline $\begin{array}{l}\text { Table 6. Of Public School Teachers Who Left Teaching, Percent Reporting } \\
\text { Various Categories of Reasons Were Very or Extremely Important to } \\
\text { Decision, by Field (2004-05) }\end{array}$ & 28 \\
\hline $\begin{array}{l}\text { Table 7. Logistic Regression Analysis of the Likelihood of Mathematics } \\
\text { and Science Teacher Turnover }\end{array}$ & 31 \\
\hline $\begin{array}{l}\text { Table 8. Logistic Regression Analysis of the Likelihood of Mathematics } \\
\text { and Science Teacher Turnover }\end{array}$ & 38 \\
\hline
\end{tabular}




\begin{abstract}
This study examines the magnitude, destinations, and determinants of the departures of mathematics and science teachers from public schools. The data are from the National Center for Education Statistics’ nationally representative Schools and Staffing Survey and its longitudinal supplement, the Teacher Follow-up Survey. Our analyses show that rates of mathematics and science teacher turnover, both those moving between schools and those leaving teaching altogether, have increased over the past two decades, but have not been consistently different than those of non-mathematics/science teachers. Mathematics and science teachers who left teaching were also no more likely than other teachers to take non-education jobs, such as in technological fields, or to be working for private business or industry. The data also show that, like other teachers, there are large school-to-school differences in mathematics and science turnover. High poverty, high minority, and urban public schools have among the highest mathematics and science turnover levels. In the case of cross-school migration, the data show there is an annual asymmetric reshuffling of a significant portion of the mathematics and science teaching force from poor to not poor schools, from high-minority to low-minority schools, and from urban to suburban schools. However, our multivariate analyses showed that a number of key organizational characteristics and conditions of schools accounted for these school differences in turnover. The strongest factors for mathematics teachers were the degree of individual classroom autonomy held by teachers, the provision of useful professional development, and the degree of student discipline problems. For science teachers, the strongest factors were the maximum potential salary offered by school districts, the degree of student discipline problems in schools, and useful professional development.
\end{abstract}




\section{The Magnitude, Destinations and Determinants of Mathematics and Science Teacher Turnover}

\section{Introduction}

Few educational issues have received more attention in the past two decades than the challenge of staffing the nation's classrooms with qualified mathematics and science teachers (see, e.g., National Commission on Excellence in Education, 1983; Darling-Hammond, 1984; National Academy of Sciences, 1987). In recent years, high-profile reports from organizations such as the John Glenn National Commission on Mathematics and Science Teaching for the 21st Century, (2000), the National Research Council (2002), and the National Academy of Sciences (2007) have directly tied mathematics and science teacher staffing problems to multiple educational and societal problems - to low U.S. educational performance compared to other nations, to the minority achievement gap, and to national economic competitiveness. There are a number of competing explanations concerning the sources of, and solutions to, these mathematics and science staffing problems. One of the most prominent explanations focuses on teacher shortages. At the root of the problem, in this view, is an insufficient production and supply of mathematics and science teachers in the face of increasing student enrollments and increasing teacher retirements. Subsequent shortages, this view continues, force many school systems to lower standards to fill teaching openings, in turn inevitably leading to high levels of underqualified mathematics and science teachers and lower student performance (e.g., National Commission on Teaching and America’s Future 1996, 1997; U.S. Department of Education, 2002). Researchers and policy analysts have long held, moreover, that these shortfalls fall disproportionately on schools in disadvantaged high-minority and high-poverty communities and 
are a major factor in unequal, and ultimately, occupational outcomes (e.g. Darling-Hammond, 1984; National Commission on Teaching and America’s Future, 1996, 1997; Quartz et al., 2008). The prevailing policy response to teacher shortages, both now and in the past, has been to attempt to increase the supply of teachers (Tyack, 1974; Lortie, 1975; Theobold, 1990; Hirsch et al., 2001; Feistritzer, 1997; Darling-Hammond, 2007; Rice et al., 2008; Liu et al., 2008; Fowler, 2008). Over the years, a wide range of initiatives have been implemented to recruit new candidates into teaching. Among these are career-change programs, such as "troops-to-teachers," designed to entice professionals into mid-career switches to teaching, and Peace Corps-like programs, such as Teach for America, designed to lure academically talented candidates into understaffed schools. Many states have instituted alternative certification programs, whereby college graduates can postpone some or all of their formal education training and begin teaching immediately. Some school districts have resorted to recruiting teaching candidates from overseas. Scholarships, financial incentives, student loan forgiveness, housing assistance, and tuition reimbursement, have all been instituted to aid recruitment. These initiatives often have been targeted in particular to mathematics and science (e.g., Liu et al., 2008; Fowler, 2008). In contrast to this historical focus on understanding the factors that attract individuals to teaching, and the means to recruit new candidates into the occupation, there has been relatively less attention paid to the role of teacher turnover, migration, mobility and attrition in these staffing problems (Theobold, 1990; Hirsch et al., 2001; Ingersoll, 2001; Rice et al., 2008).

\section{The Importance of Employee Turnover}

There is a long tradition of research in the fields of labor economics and organization theory on the consequences, positive and negative, of employee turnover for individuals, for organizations, for the larger economy, and across a range of industries and occupations (e.g., Oi, 
1962; Price 1977, 1989; Jovanovic, 1979a, 1979b; Jovanovic \& Mincer, 1981; Mobley, 1982;

Dalton et al., 1982; Becker, 1993; Abelson \& Baysinger, 1984; Hom \& Griffeth, 1995; Siebert \& Zubanov, 2009). In general, theory and research in these traditions holds that some degree of employee turnover, job, and career change is normal, inevitable, and can be efficacious for individuals, for organizations, and for the economic system as a whole (e.g., Kimmitt, 2007). Moreover, a number of analysts have held that job transition and turnover has increased in the post-World War II economy, life-long careers are decreasingly the norm, and there has been growth in the average number of jobs, employers, and careers held by individuals over their working lives (e.g., Sullivan, 1999).

On the other hand, theory and research on employee turnover have also long held that employee turnover can be both cause and effect of problems in organizations. From this perspective, employee turnover is of concern not only because it may be a symptom of underlying problems in how well organizations function, but also because departures can entail costs for organizations and for the larger system. In this literature, there is a general consensus that there are a variety of different types of costs and consequences associated with employee turnover, including the loss of firm-specific human capital, and investments in employee development, the costs of replacement hiring and training, and disruption of production processes, and that such costs vary by industry and occupation (e.g., Price, 1989).

\section{The Importance of Teacher Turnover}

In contrast to the industrial and corporate sectors, until recently there has been little research on, or attention to, the costs and benefits, functions and dysfunctions of the turnover of teaching employees in the education sector. In recent years this gap has begun to be addressed. In a companion research study we examined national data to empirically evaluate the adequacy 
of the supply of mathematics and science teachers and to empirically investigate the role of teacher turnover in mathematics and science shortages (Ingersoll \& Perda, 2010a). The data show that schools have more difficulty hiring mathematics and science teachers than any other field. But, the data show these school staffing problems are not simply a result of an insufficient production of new mathematics and science teachers. The data show that over the past two decades the supply of newly qualified mathematics and science teachers has more than kept pace with both increases in student enrollments and with increases in teacher retirements. Where the new supply is more tight is in covering preretirement teacher turnover. Unlike fields such as English, there is not a large cushion of new mathematics and science teachers relative to preretirement turnover, making schools with higher turnover more likely to have staffing problems. In short, the data document that one negative consequence of mathematics and science teacher turnover is its connection to the larger mathematics and science staffing problems that confront many schools.

There have been a growing number of efforts to identify and empirically measure the financial costs of teacher turnover (e.g., Texas Center for Educational Research, 2000; Villar \& Strong, 2007; Alliance for Excellent Education, 2005; Barnes et al., 2007; Milanowski \& Odden, 2007; also see Harris, 2009). There have also been a growing number of studies that have tried to discover whether turnover involves the loss of higher- or lower-caliber teachers by examining the relationship between teacher turnover and various measures of teacher quality, such as teachers' test scores, the selectivity of teachers' undergraduate institutions, teachers who have obtained National Board Certification, and student test-score gains (e.g., Clotfelter et al., 2006; Committee on Evaluation of Teacher Certification by the National Board for Professional Teaching Standards, 2008; Boyd et al., 2007; Goldhaber et al., 2007; Kreig, 2004). Several 
recent efforts have explored the impact of teacher turnover on school-wide performance (Levy et al., 2010; Meier \& Hicklin, 2007; Keesler, 2010). Finally, there have also been some attempts to understand the impact of teacher turnover on long-term school improvement efforts (Smylie \& Wenzel, 2003) (for a more detailed examination of research on the benefits and costs of teacher turnover, see Ingersoll \& Perda, 2010b).

Along with this growing research base, in the realm of educational policy and reform there has been increasing attention to teacher turnover and a growing consensus that teacher turnover has been a perennial problem in a substantial segment of the elementary and secondary school population, and especially in fields with staffing problems such as mathematics and science (e.g., Liu et al., 2008; National Commission on Teaching and America's Future, 2003; Alliance for Excellent Education, 2004; Behrstock, 2009). With this recognition has also come a growing demand for evidence on the sources of, and reasons behind, teacher turnover and retention, especially for fields such as mathematics and science, to provide direction on how to improve retention.

\section{Research on Mathematics and Science Teacher Turnover}

Understanding the determinants, predictors and sources of teacher turnover has been the subject of substantial empirical research (for comprehensive reviews, see, Guarino et al., 2004, 2006; Johnson et al., 2005; Zumwalt \& Craig, 2005; Borman \& Dowling, 2008). Such research has provided increasing insight into the impact on turnover of a wide range of factors, both individual and school level, both extrinsic and intrinsic. Among the findings has been that teacher turnover is related to the teaching field. Although the data have been inconsistent at times, special education, mathematics, and science are typically found to be the fields of highest turnover (Grissmer \& Kirby, 1992; Murnane et al., 1991; Rumberger, 1987; Weiss \& Boyd, 
1990; Henke et al., 2001; Ingersoll, 2006). Moreover, analysts have hypothesized that mathematics and science teachers are more likely to leave at higher rates because they are more likely than other teachers to have alternative career options in the business and technological sectors, often with higher salaries (e.g., Murnane et al., 1991; Rumberger, 1987).

However, there are important limitations to the existing empirical research—specifically for understanding and addressing mathematics and science teacher turnover. For instance, there is a dearth of information on whether mathematics and science teacher turnover is disproportionately concentrated in particular types of schools, which types of schools have higher levels of mathematics and science teacher turnover and, for those who migrate from one school to another, what kinds of schools they move to. There has been little empirical research on where mathematics and science teachers go after departing from teaching, and what kinds of jobs and occupations mathematics and science teachers leave for. Moreover, little is known about which aspects, conditions, policies and characteristics of districts and schools, especially those more amenable to policy, are related to mathematics and science teacher turnover, especially with large-scale representative data. Finally , much of the empirical research has tended to focus on, or emphasize, some components of the overall flow of teachers from schools, while omitting others. These limitations have meant that there is limited understanding of the magnitude, destinations and determinants of the attrition, turnover, and the inter-organizational mobility of mathematics and science teachers. Addressing these gaps is the objective of our study.

\section{The Study}

The objective of this study is to use nationally representative data to closely examine mathematics and science teacher turnover. There are three sets of research questions we seek to 
address:

1. Magnitude: What is the overall magnitude of mathematics and science teacher mobility and attrition? At what rates do mathematics/science teachers move from or leave their teaching jobs? How do their turnover rates compare to those of other teachers? Have their turnover rates changed over time? How much of the overall amount of turnover is concentrated in particular types of schools? Which types of schools have higher levels of mathematics/science teacher turnover?

2. Destinations: What are the destinations of mathematics/science teachers who move from or leave their teaching jobs? What proportions of those departing move to teaching jobs in other schools, quit to care for children and families, go to graduate school, retire, go into non-teaching occupations within the larger education sector (e.g., school administration, curriculum development or higher education, etc), or go into noneducational occupations? Of those who move from one school to another, do their new schools differ from their original schools, in terms of school demographic characteristics?

3. Determinants: What are the reasons for mathematics and science teacher turnover? Which particular aspects and conditions, of schools and of teachers' jobs, especially policy-amenable factors, are most tied to the turnover of mathematics and science teachers?

The theoretical perspective (see Figure 1) we adopt in our research draws from the sociology of organizations, occupations, and work and the interdisciplinary field of organization theory. Our operating premise is that in order to fully understand the causes and consequences of school turnover and staffing problems, it is necessary to examine these issues from the perspective of the schools and districts where these processes happen and within which teachers 
work. By adopting this perspective, we seek to discover the extent to which staffing problems in schools can be usefully reframed from macro-level issues, involving major societal demographic trends, to organizational-level issues, involving manipulable and policy-amenable aspects of particular districts and schools. Our focus in this report is the relationships depicted on the left side of Figure 1—examining the levels, directions and variations of mathematics and science teacher turnover and identifying the characteristics and conditions of school districts and schools that are related to these departures.

\section{Figure 1: An Organizational Perspective on the Causes and Consequences of Mathematics/Science School Staffing Problems}

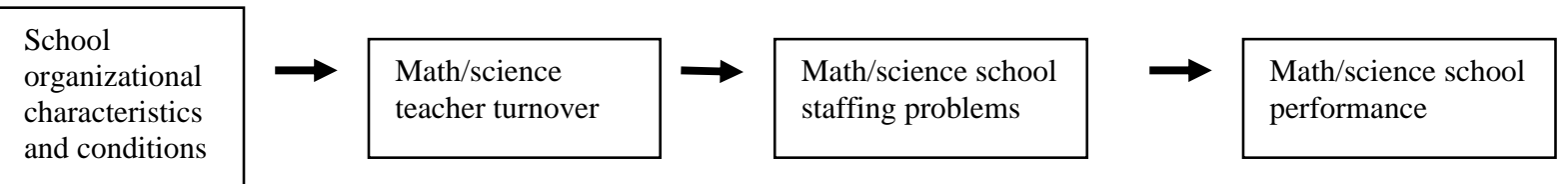

Underlying our analysis are two general interrelated premises, drawn from this perspective. The first is that fully understanding turnover requires examining it at the level of the organization. Following this perspective, here we examine what portion of the variation in turnover lies between states, or between school districts, or between schools. The level of analysis is especially important for deciding which types and components of employee separations from organizations are relevant. Research on teacher turnover has often focused on those leaving the occupation altogether, here referred to as teacher attrition, and has often deemphasized those who transfer or move to different teaching jobs in other schools, here referred to as teacher migration. The logic is that the latter moves are a less significant form of turnover because they do not increase or decrease the overall supply of teachers, as do retirements and career changes and, hence, do not contribute to overall shortages. From a systemic level of 
analysis, this may be correct. However, from an organizational-level perspective, employee migration is as relevant as employee attrition. The premise underlying our perspective is that, whether those departing are moving to a similar job in another organization or leaving the occupation altogether, their departures similarly impact and are impacted by the organization. For this reason, this distinction is rarely noted in the larger literature on employee turnover and research on other occupations and organizations almost always includes both cross-organization movers and occupational leavers (see e.g., Price, 1977). Here, we examine both.

A similar impact holds for temporary attrition—-those who leave teaching for a year or more and then return. The latter, of course, do not represent a permanent loss of human capital from the teacher supply and, hence, do not permanently contribute to overall shortages. Indeed, the re-entrance of former teachers is a major source of new supply. However, temporary attrition, like migration, can contribute to school staffing problems. Again, from an organizational perspective, temporary attrition results in a decrease in staff that usually must be replaced, regardless of whether those leaving later return to that same school or another.

A second premise underlying our theoretical perspective is that fully understanding turnover requires examining the character and conditions of the organizations within which employees work and that there can be a significant role for the management of particular schools in both the genesis of, and solution to, school staffing problems. A long tradition of research has shown that, in addition to the perceptions and characteristics of individual employees, the overall conditions of workplaces and job sites significantly affect the attachment of employees to the organization (e.g., Price, 1977; Mueller \& Price, 1990; Halaby \& Weakliem, 1989; Hom \& Griffeth, 1995; Kalleberg \& Mastekaasa, 1998; Mobley, 1982; Cotton \& Tuttle, 1986; Griffeth et al., 2000). Following this perspective, we empirically compare the relationship to turnover of 
both overall school-wide conditions and each individual's own perceptions of school conditions. This allows our analysis to assess, for instance, whether positive or negative overall organizational conditions in a school have an independent association with an individual's likelihood of retention, even if that individual, his or herself, reports more than or less than positive conditions.

In the next section, we describe our data source, define our measures, and describe our methods. In the following sections of this paper, we present our results sequentially for each of our three research questions. We then conclude by summarizing our findings and then discussing their implications for understanding and addressing mathematics and science school staffing problems.

\section{Data and Methods}

\section{Data}

The data for this study come from the National Center for Education Statistics' (NCES) nationally representative Schools and Staffing Survey (SASS) and its supplement, the Teacher Followup Survey (TFS). This is the largest and most comprehensive data source available on the staffing, occupational, and organizational aspects of elementary and secondary schools. The U.S. Census Bureau collects the SASS data for NCES from a random sample of schools stratified by state, public/private sector, and school level (For information on SASS, see NCES, 2005). There are six SASS cycles to date: 1987-88; 1990-91; 1993-94; 1999-00; 2003-04; $2007-$ 08. Each cycle of SASS includes separate, but linked, questionnaires for school and district administrators and for a random sample of teachers in each school. In addition, after 12 months, the same schools are again contacted and all those in the original teacher sample who had moved from or left their teaching jobs are given a second questionnaire to obtain information on their 
departures. This latter group, along with a representative sample of those who stayed in their teaching jobs, comprise the TFS. Unlike most previous data sources on teacher turnover, the TFS is large, comprehensive, nationally representative, includes the reasons teachers themselves give for their departures, and includes a wide range of information on the characteristics and conditions of the schools that employ teachers. It also is unusual in that it does not solely focus on a particular subset of separations, but includes all types of departures. (For information on the TFS, see Chandler et al., 2004.)

Our analysis uses data primarily from the 2003-04 SASS and the 2004-05 TFS. Our analysis uses data from the teacher, school, and district questionnaires. We focus on public schools. The 2003-04 SASS sample is comprised of 43,244 elementary and secondary teachers from 8,747 public schools. The 2004-05 TFS sample is comprised of 5,323 elementary and secondary teachers from 3,763 public schools.

This analysis uses data weighted to compensate for the over- and under-sampling of the complex stratified survey design. Each observation is weighted by the inverse of its probability of selection in order to obtain unbiased estimates of the national population of schools and teachers in the year of the survey.

\section{Measures and Methods}

Our analyses compare qualified mathematics teachers, with qualified science teachers, with all other teachers (those not qualified in either mathematics or science or both). There is a great deal of debate concerning how to define teachers as "qualified" in any given field. Here we adopt a postsecondary major-based definition—roughly equivalent to that used in the No Child Left Behind Act (NCLB). We define a teacher as qualified in a field if he or she holds an undergraduate degree, or a graduate degree, in that or a related field. We count as qualified both 
noneducation and subject-area education degrees. For mathematics, we define as qualified those who indicated they had completed an undergraduate or graduate major in mathematics or mathematics education. We define qualified science teachers as those who indicated they had completed an undergraduate or graduate major in science education, biology, physics, chemistry, earth science, another natural science, or engineering. Eighty-five percent of these qualified mathematics and science teachers are employed in departmentalized settings at the middle or secondary school levels. The remainder is employed in primary schools, often as instructors of mathematics enrichment courses. Like NCLB, we do not count as qualified those with only a teaching certificate in a field, absent a degree or major in that field. Unlike NCLB, we do not use teachers' test scores (such as Praxis) as a means of assessing qualifications in a field because our data do not have such information. Moreover, we do not base our definition of qualified teachers on a respondent's teaching assignments, where, for example, a teacher assigned to teach mathematics is assumed to be qualified in mathematics. Identifying teachers according to their fields of assignment can be in accurate because of the widespread practice of out-of-field teaching, in which teachers are assigned to teach subjects for which they have few formal qualifications (Ingersoll, 1999). We chose a major-based method of identification because it represents those teachers with a credential signifying human capital in the field - the subject of major policy concern. But, note, we do not focus on, nor distinguish, the quality, character, match, fit, effectiveness, or performance of teachers. All of the latter are, of course, crucial from both a theoretical and policy perspective. But, parallel to most analyses of labor supply and demand, we focus on qualified employees.

Our analysis is divided into two stages. In the first stage, we present mostly descriptive statistics to address our three research questions. In the second stage, we follow up with a 
detailed multiple logistic regression analysis of the predictors of turnover to further address the third research question. Below, we describe these stages of our analysis.

In the first stage, we first summarize data on rates and levels of mathematics, science, and non-mathematics/science teachers. We analyze and describe differences in turnover by location and examine the types of schools mathematics and science teachers move to and the types of jobs and occupations they leave for. We then examine the reasons teachers themselves give for their migration and attrition drawn from sets of items in the TFS questionnaire that asked teacherrespondents to indicate the importance of various factors for their departures. Self-report data such as these are useful because those departing are, of course, often in the best position to know the reasons for their departures. But, such data are based on the subjective attributions by those who had earlier departed, introducing possible attribution bias. Moreover, the items are often general (e.g., “dissatisfied with teaching”), and do not indicate which specific aspects of teaching, or of schools, are related to turnover. To address these limits, we follow up in our second stage, with a regression analysis that examines the association with turnover of a more specific set of school organizational characteristics/conditions, based on data from the full set of respondents in the 2003-04 SASS (including both those who stayed and those who later departed).

In the regression models, the dependent variable —-teacher turnover—is based on whether each teacher remained with, moved to another school, or left teaching, within one year after the 2003-04 SASS administration. The TFS, which includes only about $12 \%$ of teachers from the original SASS sample, only has a few hundred mathematics and science teachers. To increase the sample size specifically for our regression analyses, we combined the TFS measure of 
turnover, with a preliminary measure of turnover collected from school principals for the entire SASS teacher sample. ${ }^{\mathrm{i}}$

We cumulatively examine three groups of predictors of turnover: teacher characteristics, school characteristics, and organizational conditions. Table 1 provides definitions for these variables. Table 2 provides mean teacher characteristics, school characteristics, and organizational conditions associated with the teachers in the combined SASS/TFS sample.

Following previous research on teacher turnover, in the regression models we include control variables for several key individual teacher characteristics: race/ethnicity, gender, and age. Because of its U-shaped relationship, we transform age into a three-category set of dummy variables-younger (less than 30), middle-aged (31-50), and older (greater than 50). Following previous research on school organization (e.g., Bryk et al., 1990; Chubb \& Moe, 1990; Coleman \& Hoffer, 1987), in the regression models we include, as independent variables, school characteristics typically found to be important in this literature: school level, school size, the type of school locale (i.e., urban, rural, suburban), and the proportion of the student population in poverty (i.e., eligible for free or reduced lunch). ${ }^{\mathrm{ii}}$ 


\title{
Table 1: Definitions of Measures Utilized in the Regression Analysis
}

\author{
Teacher Turnover: a dichotomous variable where $1=$ not teaching in same school as last year and $0=$ \\ stayer/currently teaching in same school. \\ Teacher Characteristics \\ - Young: a dichotomous variable where $1=$ teacher less than 30 years of age and $0=$ other teachers. \\ - Old: a dichotomous variable where $1=$ teacher older than 50 years of age and $0=$ other teachers. \\ - Male: a dichotomous variable where $1=$ male teacher and $0=$ female teacher. \\ - Minority: a dichotomous variable where $1=$ nonwhite teacher and $0=$ other teachers. \\ Teacher Field \\ - Math: a dichotomous variable where $1=$ degree in math or math education and $0=$ all other teachers. \\ - Science: a dichotomous variable where $1=$ degree in one of the sciences or science education and $0=$ all other \\ teachers.

\section{School Characteristics} \\ - Rural: a dichotomous variable where $1=$ rural and $0=$ suburban or urban. \\ - Suburban: a dichotomous variable where $1=$ suburban and $0=$ rural or urban. \\ - Secondary Level: a dichotomous variable where $1=$ junior or senior secondary and $0=$ elementary or middle \\ or combined (K-12). \\ - Size: student enrollment of school. \\ - Poverty Enrollment: percentage of students eligible for the federal free or reduced-price lunch program for \\ students from families below poverty level \\ Organizational Characteristics/Conditions \\ - Highest Salary: for districts with a salary schedule for teachers, normal yearly base salary highest step, or if \\ no district salary schedule, the highest teacher yearly base salary, as reported by school administrators. \\ - Student Discipline Problems: on a scale of $1=$ never happens to $5=$ happens daily, the school mean of \\ teachers' reports for eight kinds of student discipline problems: disruptive behavior; absenteeism; physical \\ conflicts among students; robbery; vandalism; weapon possession; physical abuse of teachers; verbal abuse of \\ teachers.
}

- School Leadership Support: on a scale of $1=$ strongly disagree to $4=$ strongly agree, the school mean of teachers' reports for four items: principal communicates expectations; administration is supportive; principal enforces rules for student discipline; principal communicates objectives; staff are recognized for job well done.

- School Resources: on a scale of $1=$ strongly disagree to $4=$ strongly agree, the school mean of teachers' reports for one item: necessary materials such as textbooks, supplies and copy machines are available as needed by the staff.

- School-wide Faculty Influence: on a scale of $1=$ none to $4=$ a great deal, the school mean of collective faculty influence over seven areas: student performance standards; curriculum; content of in-service programs; evaluating teachers; hiring teachers; school discipline policy; deciding spending of budget.

- Classroom Teacher Autonomy: on a scale of $1=$ none to $4=$ a great deal, the school mean of individual teacher's control over six areas: selecting textbooks and other instructional materials; selecting content, topics and skills to be taught; selecting teaching techniques; evaluating and grading students; determining the amount of homework to be assigned; disciplining students.

- Student-Discipline-Focused Professional Development: on a scale of $1=$ not receive or not useful to $4=$ very useful, the school mean of teachers' reports of the usefulness of any professional development activities that focused on student discipline and management in the classroom.

- Subject-Content-Focused Professional Development: on a scale of $1=$ not receive or not useful to $4=$ very useful, the school mean of teachers' reports of the usefulness of any professional development activities that focused on the content of the subjects they taught.

We used factor analysis (with varimax rotation method) to evaluate our indices of student discipline problems, school leadership, faculty influence and teacher autonomy. We considered item loadings of at least .4 necessary for inclusion in a factor. No items loaded on more than one factor. Each factor had high internal consistency (a > .7). The measures of student discipline problems, leadership, resources, faculty influence, teacher autonomy and professional development are all school means of the reports of the total SASS teacher sample for each school and not limited to the reports of those in the smaller TFS sample. 


\section{Table 2: Descriptive Statistics for Independent Variables Utilized in Regression Analysis}

\begin{tabular}{lccc}
\hline & \multicolumn{3}{c}{ Proportion } \\
\cline { 2 - 4 } Categorical Predictor Variables & All Teachers & Mathematics & Science \\
\hline Teacher Characteristics & & & \\
\hline Young & .17 & .17 & .14 \\
Old & .30 & .29 & .30 \\
Male & .25 & .39 & .47 \\
Minority & .17 & .15 & .18 \\
Teacher Field & & & \\
$\quad$ Mathematics & .05 & 1.0 & 0.0 \\
Science & .07 & 0.0 & 1.0 \\
School Characteristics & & & .18 \\
$\quad$ Rural & .19 & .21 & .50 \\
Suburban & .52 & .55 & .59 \\
Secondary & .30 & .66 & \\
\hline
\end{tabular}

\begin{tabular}{|c|c|c|c|}
\hline \multirow[b]{2}{*}{ Continuous Predictor Variables } & \multicolumn{3}{|c|}{$\begin{array}{c}\text { Mean } \\
\text { (Std. Dev.) }\end{array}$} \\
\hline & All Teachers & Mathematics & Science \\
\hline \multicolumn{4}{|l|}{ School Characteristics } \\
\hline School Size (in 100s) & $\begin{array}{c}8.04 \\
(6.07)\end{array}$ & 10.97 & $\begin{array}{l}10.74 \\
(7.45)\end{array}$ \\
\hline Poverty Enrollment ( in 10s) & $\begin{array}{c}4.12 \\
(2.93)\end{array}$ & $\begin{array}{c}3.28 \\
(2.50)\end{array}$ & $\begin{array}{c}3.77 \\
(2.85)\end{array}$ \\
\hline \multicolumn{4}{|l|}{ Organizational Characteristics/Conditions } \\
\hline Highest Salary (in 10,000s) & $\begin{array}{c}6.08 \\
(1.30)\end{array}$ & $\begin{array}{c}6.01 \\
(1.29)\end{array}$ & $\begin{array}{c}6.15 \\
(1.32)\end{array}$ \\
\hline Student Discipline Problems (scale 1-5) & $\begin{array}{c}2.29 \\
(0.71)\end{array}$ & $\begin{array}{c}2.43 \\
(0.69)\end{array}$ & $\begin{array}{c}2.52 \\
(0.72)\end{array}$ \\
\hline School Leadership Support (scale 1-4) & $\begin{array}{c}3.32 \\
(0.65)\end{array}$ & $\begin{array}{c}3.24 \\
(0.66)\end{array}$ & $\begin{array}{c}3.21 \\
(0.66)\end{array}$ \\
\hline School Resources (scale 1-4) & $\begin{array}{c}3.14 \\
(0.89)\end{array}$ & $\begin{array}{c}3.25 \\
(0.84)\end{array}$ & $\begin{array}{c}3.06 \\
(0.93)\end{array}$ \\
\hline Faculty Influence (scale 1-4) & $\begin{array}{c}2.21 \\
(0.61)\end{array}$ & $\begin{array}{c}2.18 \\
(0.59)\end{array}$ & $\begin{array}{c}2.13 \\
(0.60)\end{array}$ \\
\hline Teacher Autonomy (scale 1-4) & $\begin{array}{l}3.38 \\
(0.52)\end{array}$ & $\begin{array}{c}3.39 \\
(0.46)\end{array}$ & $\begin{array}{c}3.37 \\
(0.52)\end{array}$ \\
\hline $\begin{array}{l}\text { Discipline-Focused Prof. Dev. } \\
\text { (scale 1-4) }\end{array}$ & $\begin{array}{l}1.77 \\
(1.04)\end{array}$ & $\begin{array}{l}1.57 \\
(0.92)\end{array}$ & $\begin{array}{l}1.62 \\
(0.95)\end{array}$ \\
\hline Content-Focused Prof. Dev. (scale 1-4) & $\begin{array}{c}2.64 \\
(1.03)\end{array}$ & $\begin{array}{l}2.45 \\
(1.05)\end{array}$ & $\begin{array}{l}2.46 \\
(1.09)\end{array}$ \\
\hline
\end{tabular}

Note: Means and deviations are at the teacher level and associated with teachers in the sample. 
Finally, after controlling for the above teacher and school factors, we focus on the relationship to turnover of eight key aspects of the organizational character and conditions in schools: teacher salary, student discipline problems, leadership and support, school resources, faculty school-wide decision-making influence, teacher classroom autonomy, PD activities focused on student discipline and classroom management, and PD activities focused on the teacher's subject-area content. This study does not attempt to provide a comprehensive analysis of all the many aspects of schools that may possibly impact the turnover of mathematics and science teachers. We focus on this set of eight particular characteristics of schools because they have long been considered among the important aspects of effective school organization (see, e.g., Goodlad, 1984; Coleman \& Hoffer, 1987; Grant, 1988; Chubb and Moe, 1990; Bryk et al., 1990), are ostensibly policy amenable, and are available from our data source.

Unlike most empirical analyses that use either individual teacher's salaries or the school's mean teacher salary, we use the normal yearly base salary for teachers at the highest step on the district salary schedule because it better assesses differences in the organizational-level compensation structure.iii For the measure of student discipline problems within the organization we use an index of eight items on student misbehavior, crime, abuse, conflict, disrespect, and theft within schools, as reported by teachers. For the measure of school leadership and support we utilize an index of five items on the degree of assistance, the expectations, recognition, and leadership communicated or provided to the faculty by the school principal, as reported by teachers. For the measure of school resources, we use one item on the degree to which necessary materials and resources are provided, as reported by teachers. For the measure of school-wide faculty decision-making influence, we use an index of seven items on the degree of collective faculty input into decisions concerned with school policies over budgets, the curriculum, hiring, 
standards, student discipline, PD, and teacher evaluation, as reported by teachers. For the measure of teacher classroom autonomy, we use an index of six items on the degree of individual teacher control in their classrooms over course content, textbook choice, homework, student discipline, student evaluation, and techniques, as reported by teachers. For the measures of PD activities, we utilize two items on the usefulness of activities focused on student discipline and classroom management and also on subject-area content, as reported by teachers.

This second stage of the analysis examines whether the likelihood of individual teachers moving from or leaving their teaching jobs is related to the above measures of school organizational characteristics and conditions, while controlling for individual-level characteristics of teachers and school demographic characteristics. To discern if, and to what extent, mathematics and science teachers' likelihood of departure are more or less likely to be related to our range of school characteristics and organizational conditions, in our models we include interaction terms between each of these predictors and our measures for both mathematics and science teachers. Because different school organizational conditions are often interrelated, and their relations to turnover possibly confounded, along with a full model, we also estimate the coefficients for each measure of school organizational conditions in a separate model in order to avoid the problem of multicollinearity.

As mentioned above, our measures of organizational conditions, other than salaries, are based on teachers' self reports. Teachers’ responses within any individual school, of course, may vary because teachers within the same building may differ as to how positive or negative they perceive various conditions to be. In background analyses we partitioned the variance of each measure of organizational conditions into within-school and between-school components. The intraclass correlation, or the portion of the variation that lies between schools, ranged from 
$13 \%$ for subject-area PD to $43 \%$ for student discipline, indicating that part of each measure is unique to each teacher respondent and that part is common to all teachers within a school. To try to capture and compare both components in our analyses, we used two types of measures of organizational conditions: averages across the teachers in each school, and the extent to which individual teachers differed from others in their building. In our models, use of the schoolaverage measures tells us whether particular organizational conditions on average are related to turnover; the teacher-deviation measures tell us whether individuals who perceived conditions differently than other faculty in their school were also more or less likely to depart than others. Following our organizational perspective, this allows our analysis to compare the direction and magnitude of the relationship with turnover of school-wide conditions versus an individual's own perceptions. This also allows us to partly address the issue of attribution bias, mentioned earlier. For instance, a highly satisfied or highly disgruntled individual might be more or less likely to depart, while also over or underestimating organizational conditions, making it appear there is a relationship between the two. Using separate measures for school averages and individual deviations allows us to partly address this individual bias.

This strategy of separating school characteristics into school-level and teacher-level indicators has a strong foundation in multilevel or hierarchical modeling (Raudenbush \& Bryk, 2002) and contextual effects analysis (Iversen, 1991). These include multilevel analyses in which variables representing group means and contextual characteristics are included as predictors in the model and individual variables are expressed as deviations from the group means (Raudenbush \& Bryk, 2002, p. 33; Kreft et al., 1995). Here, following our organizational perspective, we examine and compare organizational conditions as contextual effects versus individual effects. 
Our analysis used PROC GENMOD in SAS (version 9.2) because it adjusts for the nonrandom clustering of teachers within schools resulting from the multilevel structure of the sample and uses within and between-school predictor variables to estimate separate effects across multiple levels. This procedure also supports logistic regression and allows for the inclusion of sampling design weights. Use of weights is necessary because the SASS and TFS samples over- or under-sample certain segments of the teaching population. While the TFS data are longitudinal in the sense that the turnover outcomes transpired a year after the collection of the SASS measures of school characteristics and organizational conditions, it is important to note that any relationships found between these variables and turnover represent statistical associations between measures and do not imply causality.

\section{Results}

\section{The Magnitude of Mathematics and Science Teacher Turnover}

Elementary and secondary teaching is one of the largest occupations in the U.S.- - it represents $4 \%$ of the entire nationwide civilian workforce. There are, for example, over twice as many K-12 teachers as registered nurses and five times as many teachers as either lawyers or professors (U.S. Bureau of the Census, 2008). Numerically, there are also large flows of teachers into, between, and out of schools each year. For instance, the SASS data show that at the beginning of the 2003-04 school year, about 49,600 mathematics and science teachers were hired into public schools in which they had not taught the prior year. By the following school year, about 51,400 mathematics and science teachers-equivalent to $103 \%$ of those who entered schools at the beginning of the year-departed their public schools. Hence, before, during and after the 2003-04 school year there were over 100,000 job transitions by mathematics and 
science teachers-representing over one quarter of the entire mathematics/science public school teaching force of 368,575.

The TFS data also show that from the late 1980s to 2004, annual rates of total turnover for public school mathematics and science teachers, while fluctuating from year to year, overall rose—by $33 \%$ for mathematics and by $11 \%$ for science (see Table 3). But, the data also show, surprisingly, that during this period mathematics and science teachers have not moved from or left their public schools at consistently different rates from other teachers, such as in English and social studies.

The data also show the flows of teachers out of schools have not been equally distributed, vary greatly by location, are highly concentrated in a relatively small portion of the school population, and are tied to the demographic characteristics of schools.

To discern the sites or sources of variation, we conducted an analysis of the crosslocation variance of the SASS/TFS data on turnover. The data showed that variation in turnover is far greater between schools within states, than between states and, moreover, that turnover is far greater between schools than between districts. In other words, the largest variations in rates of teacher turnover by location are those between different schools, even within the same district. $^{\text {iv }}$ This provides support for our organizational-level theoretical perspective.

To examine the distribution of turnover across schools and to discern the degree to which turnover is concentrated, we aggregated the SASS/TFS data on turnover to the school level and then subdivided the population of schools into quartiles based on school-level turnover rates. ${ }^{\mathrm{v}}$ The data showed that the bottom quartile of schools had an average annual turnover rate of $8 \%$. These schools accounted for just $14 \%$ of all teacher turnover in 2004-05. In contrast, the top $25 \%$ of public schools had an average annual turnover rate of $32 \%$ and accounted for $45 \%$ of all 
turnover in that year. We were not able to conduct either the above cross-location analysis of variance, or the above school aggregation analysis, on mathematics/science teachers alone because of their smaller sample size. However, we suspect that the results for mathematics and science would differ little, because our other analyses show similar cross-location differences in turnover for mathematics and science teachers. Similar to other teachers, we found school demographic characteristics_-poverty enrollments, minority enrollments, and the urbanicity of the school's community—-were among the school characteristics most correlated with mathematics and science teacher turnover. That is, poor, minority, and urban public schools have among the highest mathematics and science turnover levels, both for those moving to other schools and those leaving teaching altogether.

Table 3. Percent Annual Public School Teacher Migration and Attrition, by Field, and by Year

\begin{tabular}{cccc|ccc|ccc}
\hline \multicolumn{4}{c}{ Non Math/Science } & \multicolumn{3}{c}{ Math } & \multicolumn{3}{c}{ Science } \\
\hline Year & Moves & Leaves & Total & Moves & Leaves & Total & Moves & Leaves & Total \\
\hline $1988-89$ & 8.1 & 5.7 & 13.8 & 7.1 & 5.1 & 12.2 & 6.2 & 4.9 & 11.1 \\
$1991-92$ & 7.3 & 5.3 & 12.6 & 7.1 & 3.5 & 10.6 & 7.3 & 5.0 & 12.3 \\
$1994-95$ & 7.1 & 6.6 & 13.7 & 7.7 & 7.0 & 14.7 & 8.1 & 5.2 & 13.3 \\
$2000-01$ & 7.7 & 7.4 & 15.1 & 7.3 & 6.4 & 13.7 & 7.5 & 9.0 & 16.5 \\
$2004-05$ & 8.3 & 8.4 & 16.7 & 9.1 & 7.1 & 16.2 & 5.1 & 7.2 & 12.3 \\
\hline
\end{tabular}

\section{The Destinations of Mathematics and Science Teacher Turnover}

What are the destinations of mathematics/science teachers who moved from or left their teaching jobs? The TFS data show that in 2004-05 about 25,000 of those departures moved to other schools and about 26,400 left classroom teaching altogether. Of those who left classroom teaching altogether, just under a third retired (Table 4). Interestingly, another third of leavers were job shifters who left classroom teaching but did not leave education; they took other jobs in the larger education sector, such as in school administration, curriculum development, or 
educational publishing. ${ }^{\mathrm{vi}}$ Far fewer left to work outside of education, to care for family members (predominantly for pregnancy and raising children), or to enroll full-time in university or college programs. Surprisingly, mathematics and science teachers were not more likely than other teachers, at a statistically significant level, to leave classroom teaching to take non-education jobs, such as in technological fields. Moreover, in further analysis of these data we found that, of those who left for non-education jobs, mathematics and science teachers were no more likely than others to be working for private business or industry.

Table 4: Percent Public School Teacher Migration and Attrition, by New Schools of Movers and by Main Occupational Status of Leavers, and by Field (2004-05)

\begin{tabular}{lccc}
\hline & $\begin{array}{c}\text { Non } \\
\text { Math/Science }\end{array}$ & Math & Science \\
\hline Mover's New Schools & 25 & 27 & 17 \\
$\quad$ Another public school within same district & 23 & 29 & 22 \\
Another public school in different district & 1 & .2 & 3 \\
$\quad$ Private school & 49 & 56 & 42 \\
Total Movers & & & \\
Leaver's Main Occupational Statuses & & & \\
Retired & 15 & 13 & 17 \\
Job in education, but not k-12 teaching & 14 & 17 & 22 \\
Caring for family members & 7 & 1 & 2 \\
Non-education job & 6 & 8 & 9 \\
Unemployed & 2 & .1 & 4 \\
Student at university/college & 2 & 2 & 4 \\
Disabled & .5 & 0 & .2 \\
Other & 4 & 3 & 1 \\
Total Leavers & 51 & 44 & 58 \\
\hline
\end{tabular}

Of those who moved to other schools, a large portion were cross-school transfers within the same school district. (see Table 4) Just over half of the migrants went to teaching jobs in other districts, most within the same state. About $5 \%$ of all public school mathematics/science movers went to private schools; about double this number moved in the reverse direction—from private to public. Compared to science and other teachers, mathematics teachers appear in Table 
4 to have had higher cross-school and cross-district teaching job mobility—but these differences are not at a statistically significant level.

In addition, we more closely examined the characteristics of the destination schools of cross-school migrants to discern the degree of symmetry in math/science teachers' moves to and from different types of schools (small sample sizes necessitated combining math with science teachers in this part of the analysis). The data show that, interestingly, math and science teachers who moved between schools were most likely to go to schools that were similar demographically. For instance, well over half of the teachers who moved from high-poverty or high-minority schools in 2004-05 migrated to schools with similar poverty and minority enrollments. Moreover, of all of those who moved from high-poverty schools, the percentage that went to low-poverty schools, was similar to the percentage in the reverse direction, i.e. of all those moving from low-poverty schools, the percentage that went to high-poverty schools. However, because math/science teachers in poor, minority and urban public schools had far higher rates of out-migration, there ended up being a net gain and loss for schools, according to school demographic differences. For instance, as shown in figure 2, of math/science teachers who moved between the 2004 and 2005 school years, over four times as many went from highpoverty schools to low-poverty schools as in reverse. ${ }^{\text {vii }}$ Likewise, of math/science teachers who moved, over 3 times as many went from urban to suburban schools, as in reverse. The net result is a large annual asymmetric reshuffling within the school system of a significant portion (about 25,000 in 2004-05) of the math/science teaching force, with a net loss on the part of poor, minority and urban schools and a net gain to non-poor, non-minority, and suburban schools. These patterns are similar for the non-math/science portion of the teaching force and provide 
further support for our theoretical perspective that fully understanding the staffing problems of schools requires examining them from the perspective of the organizations in which they occur.

\section{Figure 2: Number of Math/Science Teachers Who Moved To and From Particular Types of Public Schools (2004-2005)}

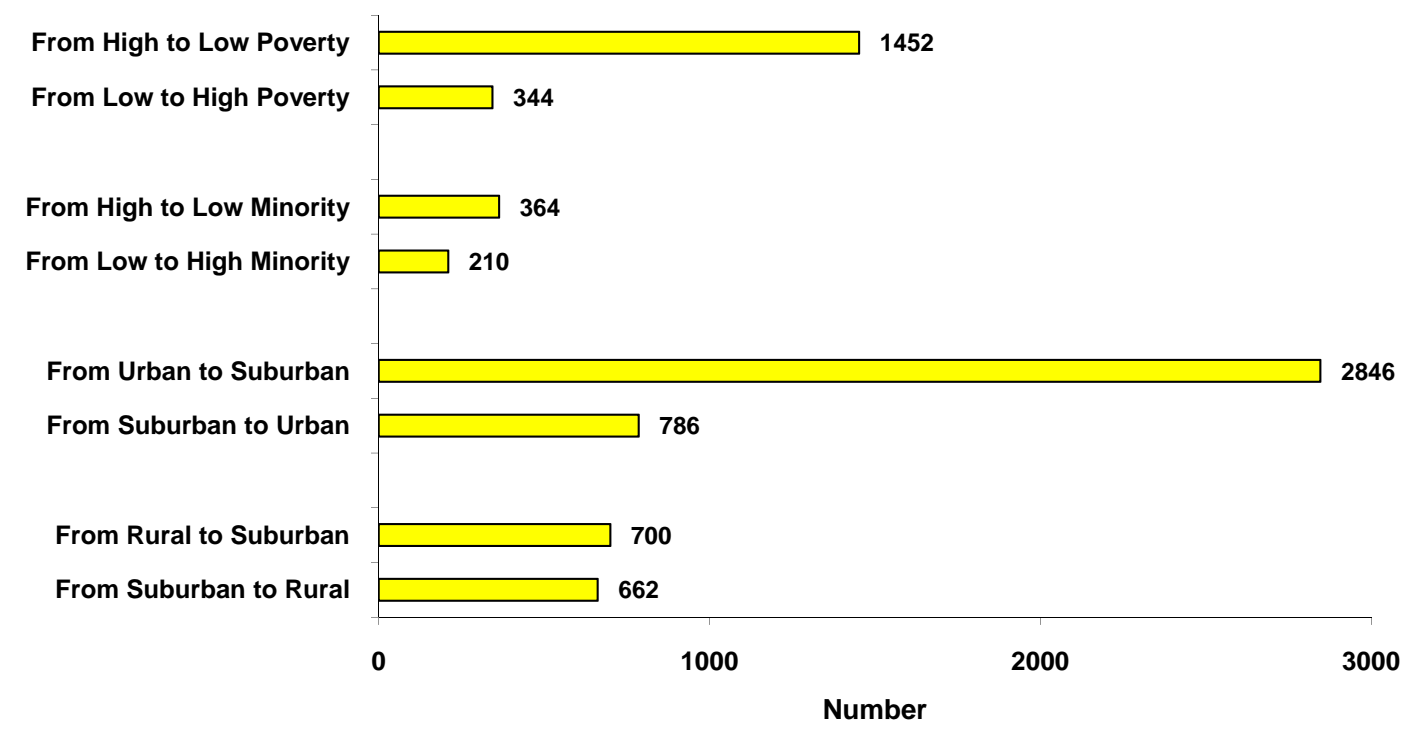

\section{The Determinants of Mathematics and Science Teacher Turnover}

These data also raise the important question: What are the reasons for and sources of these levels and patterns of mathematics and science teacher turnover? One method of answering this question is to ask those who have moved or left why they did so. Tables 5 and 6 present data on the percentage of teachers in the TFS who reported that particular reasons were "very" or "extremely" important in their decisions to move or leave, on a five-point scale from "not important” to "extremely important." We grouped the individual reasons into categories as shown. Note that the percentages in the tables add up to more than $100 \%$, because respondents could indicate more than one reason for their departures. (Also note that these self-reported reasons overlap content-wise with the self-reported data on current occupational status, presented earlier in Table 4.) 
As expected, retirement is a leading reason for those who left teaching, although less so for science teachers (Table 6). Smaller portions of both movers and leavers indicated that their moves or leaves were a result of school staffing actions—-such as their school being closed, being individually laid off, transferred, reassigned, or fired. Mathematics teachers were less likely to be transferred to other schools; on the other hand, science teachers were more likely to be laid off- accounting for almost $20 \%$ of their attrition and almost double that of mathematics teachers. However, the reasons for either of these findings are unclear from these data.

\section{Table 5: Of Public School Teachers Who Moved to Other Schools, Percent Reporting Various Categories of Reasons Were Very or Extremely Important to Decision, by Field (2004-05)}

\begin{tabular}{lcrc}
\hline & $\begin{array}{c}\text { Non } \\
\text { Math/Science }\end{array}$ & Math & Science \\
\hline School Staffing Action & 19.4 & 1.3 & 17.5 \\
Family or Personal & 26.1 & 30.9 & 27.0 \\
To Pursue Other Job or Dissatisfaction & 68.5 & 74.2 & 82.7 \\
\hline
\end{tabular}

Note. In Table 5, we grouped 11 reasons for moving in the questionnaire into three categories, as follows:

(1) School Staffing Action: layoff/involuntary transfer;

(2) Family or Personal: new school closer to home;

(3) To Pursue Other Job/Dissatisfaction: for better salary or benefits; felt job security higher at another school; opportunity for better teaching assignment at new school (subject or grade level); dissatisfied with workplace conditions; dissatisfied with support from administration; dissatisfied with job responsibilities; lack of autonomy; dissatisfied with opportunities for professional development; dissatisfied with old school for other reasons. 
Table 6: Of Public School Teachers Who Left Teaching, Percent Reporting Various Categories of Reasons Were Very or Extremely Important to Decision, by Field (2004-05)

\begin{tabular}{lccc}
\hline & $\begin{array}{c}\text { Non } \\
\text { Math/Science }\end{array}$ & Math & Science \\
\hline Retirement & 32.1 & 29.1 & 22.5 \\
School Staffing Action & 14.6 & 10.1 & 19.7 \\
Family or Personal & 44.7 & 49.1 & 18.1 \\
To Pursue Other Job or Dissatisfaction & 46.1 & 48.4 & 61.8 \\
\hline
\end{tabular}

Note. In Table 6, we grouped 12 reasons for leaving in the questionnaire into four categories, as follows:

(1) Retirement;

(2) School Staffing Action: reduction-in-force/layoff/school closing/reassignment;

(3) Family or Personal: change in residence; pregnancy/child rearing; health; other family or personal reasons; and

(4) To Pursue Other Job/Dissatisfaction: for better salary or benefits; to pursue position other than that of k-12 teacher; to take courses to improve career opportunities within education sector; to take courses to improve career opportunities outside of education sector; dissatisfied with teaching as career; dissatisfied with previous school or teaching assignment.

A significant portion of teacher outflows, both moving and leaving, were highly influenced by personal and family factors—a spouse's job requires a move, health issues, closer proximity to a school, a desire to raise a family. These types of job transitions are, no doubt, normal occurrences in any workplace, occupation, or industry. However, science teachers were far less likely to leave for this set of reasons. Again, it is unclear why from these data; perhaps it may be due to gender differences and child rearing as a reason; the data show science has fewer female teachers than most fields, including mathematics (see Table 2 above).

The most prominent set of factors, behind both moving and leaving, according to teachers, was a desire to obtain a better job or career, or dissatisfaction with some aspect of their teaching job. This was even more true for science teachers. While $22 \%$ of science teachers who left teaching indicated retirement was a major reason, $62 \%$ reported a major reason was dissatisfaction or desire for a better job. Unlike the first three categories in Tables 5 and 6 (retirement, school staffing actions, and family/personal), the last category (pursuing a different 
career or dissatisfaction) could more often be a voluntary choice and more often tied to the character of the schools as organizations and teaching as a job-potentially policy-amenable factors. But, as discussed in the Data/Methods section, there are limitations to these self-report data on reasons for turnover. It is, for instance, unclear what factors in particular are behind the large portions of mathematics and science moving and leaving for better jobs or because of dissatisfaction.

We follow up below with our multivariate analysis that examined a more specific set of school organizational characteristics and conditions, based on data from the full set of respondents in SASS, while controlling for other factors, such as teacher age, gender and school grade level, size and poverty.

\section{Individual, School and Organizational Predictors of Turnover}

We estimated a series of regression models using the SASS/TFS data to examine whether our collection of measures of school organizational characteristics and conditions were associated with teacher turnover. The predictor variables and associated regression estimates from each model are shown in Table 7 below. We separately entered each of the organizational condition variables into a basic model that included only controls for basic teacher and school characteristics. To evaluate whether relationships between the predictors and turnover differed by field-between mathematics teachers and science teachers, and non-mathematics/science teachers_-each analysis included measures of interactions between the predictors and the two mathematics and science teacher field variables. We tested all possible interactions in each model, but displayed only those which showed significance at least at the .10 level. $^{\text {viii }}$

Our analyses show that a number of the individual characteristics of teachers, both mathematics/science and others, were related to their likelihood of staying or departing at a 
statistically significant level, after controlling for other factors. Among the teacher background variables, the age of teachers was the most salient predictor of the likelihood of their turnover. Both younger (less than 30) and older (greater than 50) teachers were more likely to depart than are middle-aged teachers. For instance, the relative odds of young teachers departing were just over 2 times higher (i.e., $\exp (0.75)=2.11$ ) than for middle-aged teachers. Male teachers were slightly more likely to depart than were female teachers and minority teachers were not more or less likely to depart than were white teachers.

After controlling for other characteristics, having a degree in mathematics and/or science was also related to turnover. Although the coefficient was only marginally significant in two of the eight models, the odds of a mathematics teacher departing were up to $42 \%$ higher (i.e., $\exp (0.35)=1.42)$ than non-mathematics/science teachers. This finding is in stark contrast with the result that across all eight models, science teachers had an odds of departing that was $16 \%$ to $19 \%$ lower (i.e., $\exp (-0.17)=0.84$ and $\exp (-0.21)=0.81)$ than non-mathematics $/$ science teachers. Consistent with the bivariate data in Table 3, even after controlling for other factors, in 2004-05 science teachers had lower turnover than others. 
Table 7: Logistic Regression Analysis of the Likelihood of Mathematics and Science Teacher Turnover

\begin{tabular}{|c|c|c|c|c|}
\hline & Model 1 & Model 2 & Model 3 & Model 4 \\
\hline School N & 6,627 & 7,795 & 7,795 & 7,795 \\
\hline Teacher N & 34,375 & 40,195 & 40,195 & 40,195 \\
\hline Intercept & $-2.19^{* * *}$ & $-2.01^{* * *}$ & $-2.12^{* * *}$ & $-2.12^{* * *}$ \\
\hline \multicolumn{5}{|l|}{ Teacher Characteristics } \\
\hline Young & $0.75^{* * *}$ & $0.68^{* * *}$ & $0.69^{* * *}$ & $0.69^{* * *}$ \\
\hline Old & $0.31^{* * *}$ & $0.26^{* * *}$ & $0.27^{* * *}$ & $0.27^{* * *}$ \\
\hline Male & $0.20^{* *}$ & $0.17^{* *}$ & $0.18^{* *}$ & $0.19^{* * *}$ \\
\hline Minority & -0.04 & 0.06 & 0.04 & 0.03 \\
\hline \multicolumn{5}{|l|}{ Teacher Field } \\
\hline 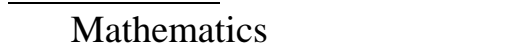 & $0.35^{\sim}$ & 0.25 & 0.25 & 0.28 \\
\hline Science & $-0.17^{\sim}$ & $-0.21^{*}$ & $-0.20^{*}$ & $-0.19^{*}$ \\
\hline \multicolumn{5}{|l|}{ School Characteristics } \\
\hline Rural & $-0.22^{*}$ & $-0.16^{*}$ & $-0.21^{* *}$ & $-0.19^{*}$ \\
\hline Suburban & -0.03 & -0.01 & -0.03 & -0.04 \\
\hline Secondary & 0.01 & -0.05 & 0.01 & 0.01 \\
\hline School Size (in 100s) & 0.00 & $-0.01^{*}$ & -0.01 & -0.01 \\
\hline School Size (in 100s) $\mathrm{x}$ & $-0.04^{* *}$ & $-0.03^{*}$ & $-0.03^{*}$ & $-0.03^{*}$ \\
\hline Mathematics & & & & \\
\hline Poverty Enrollment (in10s) & $0.05^{* * *}$ & $0.02^{\sim}$ & $0.04^{* * *}$ & $0.04^{* *}$ \\
\hline \multicolumn{5}{|l|}{ Organizational } \\
\hline \multicolumn{5}{|l|}{ Characteristics/Conditions } \\
\hline Highest Salary (in 10,000s) & -0.02 & & & \\
\hline Science x Highest Salary & $-0.16^{*}$ & & & \\
\hline \multicolumn{5}{|l|}{ Student Discipline Problems } \\
\hline$\frac{\text { School-Level }}{\text { S }}$ & & $0.28^{* * *}$ & & \\
\hline Teacher-Level & & $0.14^{*}$ & & \\
\hline \multicolumn{5}{|l|}{ School Leadership Support } \\
\hline School-Level & & & $-0.23^{* * *}$ & \\
\hline Teacher-Level & & & $-0.15^{* *}$ & \\
\hline \multicolumn{5}{|l|}{ School Resources } \\
\hline School-Level & & & & $-0.10^{\sim}$ \\
\hline Teacher-Level & & & & $-0.11^{* *}$ \\
\hline
\end{tabular}

Note. ${ }^{\mathrm{p}}<.10,{ }^{*} \mathrm{p}<.05,{ }^{* *} \mathrm{p}<.01,{ }^{* * *} \mathrm{p}<.001$ 
Table 7 (Continued): Logistic Regression Analysis of the Likelihood of Mathematics and Science Teacher Turnover

\begin{tabular}{|c|c|c|c|c|}
\hline & Model 5 & Model 6 & Model 7 & Model 8 \\
\hline School N & 7,795 & 7,795 & 7,795 & 7,795 \\
\hline Teacher N & 40,195 & 40,195 & 40,195 & 40,195 \\
\hline Intercept & $-2.11^{* * *}$ & $-2.14^{* * *}$ & $-2.14^{* * *}$ & $-2.13^{* * *}$ \\
\hline \multicolumn{5}{|l|}{ Teacher Characteristics } \\
\hline Young & $0.69^{* * *}$ & $0.68^{* * *}$ & $0.69^{* * *}$ & $0.67^{* * *}$ \\
\hline Old & $0.25^{* * *}$ & $0.26^{* * *}$ & $0.26^{* * *}$ & $0.26^{* * *}$ \\
\hline Male & $0.19^{* *}$ & $0.19^{* * *}$ & $0.18^{* *}$ & $0.15^{* *}$ \\
\hline Minority & 0.04 & 0.03 & 0.04 & 0.05 \\
\hline \multicolumn{5}{|l|}{ Teacher Field } \\
\hline Mathematics & 0.26 & $0.35^{\sim}$ & 0.23 & 0.22 \\
\hline Science & $-0.19^{*}$ & $-0.20^{*}$ & $-0.19^{*}$ & $-0.19^{*}$ \\
\hline \multicolumn{5}{|l|}{ School Characteristics } \\
\hline $\begin{array}{l}\text { Rural } \\
\end{array}$ & $-0.20^{*}$ & -0.11 & $-0.21^{* *}$ & $-0.22^{* *}$ \\
\hline Suburban & -0.04 & -0.01 & -0.04 & -0.04 \\
\hline Secondary & 0.02 & 0.1 & 0.03 & 0.01 \\
\hline School Size (in 100s) & -0.01 & -0.01 & -0.01 & -0.01 \\
\hline School Size (in 100s) x Mathematics & $-0.03^{* *}$ & $-0.04^{* *}$ & $-0.04^{* *}$ & $-0.03^{*}$ \\
\hline Poverty Enrollment (in10s) & $0.04^{* *}$ & $0.03^{* *}$ & $0.04^{* * *}$ & $0.04^{* * *}$ \\
\hline \multicolumn{5}{|l|}{ Organizational Characteristics/Conditions } \\
\hline \multicolumn{5}{|l|}{ Faculty Influence } \\
\hline School-Level & $-0.26^{* * *}$ & & & \\
\hline Teacher-Level & -0.01 & & & \\
\hline \multicolumn{5}{|l|}{ Teacher Autonomy } \\
\hline School-Level & & $-0.46^{* * *}$ & & \\
\hline School-Level x Mathematics & & $-0.75^{*}$ & & \\
\hline School-Level x Science & & $0.47^{\sim}$ & & \\
\hline Teacher-Level & & $-0.16^{* *}$ & & \\
\hline \multicolumn{5}{|l|}{ Discipline-Focused Prof. Dev. } \\
\hline School-Level & & & 0.03 & \\
\hline School-Level x Mathematics & & & $-0.50^{*}$ & \\
\hline Teacher-Level & & & -0.03 & \\
\hline \multicolumn{5}{|l|}{ Content-Focused Prof. Dev. } \\
\hline School-Level & & & & -0.09 \\
\hline Teacher-Level & & & & $-0.11^{* * *}$ \\
\hline Teacher-Level x Mathematics & & & & $-0.20^{*}$ \\
\hline
\end{tabular}

Note. ${ }^{\sim} \mathrm{p}<.10,{ }^{*} \mathrm{p}<.05,{ }^{* *} \mathrm{p}<.01,{ }^{* * *} \mathrm{p}<.001$ 
Some of the school characteristics were also related to turnover. School poverty stood out as a key variable. In general, teachers had statistically significantly higher rates of turnover in higher-poverty schools than in lower-poverty schools. A ten percentage point increase in the proportion of students eligible for free or reduced lunch was associated with a 2 to $5 \%$ increase in the odds of teachers departing. This poverty effect was no different for mathematics or science teachers than others; the results across the eight models show the interaction between poverty and field was not significant.

After controlling for other factors, teachers in rural schools were up to $20 \%$ less likely to depart than were those in urban schools. Although suburban schools had statistically lower turnover in the bivariate analysis, once other factors, such as school poverty, were controlled there was little difference in turnover between suburban and urban schools. Also, the likelihood of turnover from secondary schools was little different than turnover from elementary and K-12 combined schools. In model 2, teachers in smaller schools departed at slightly higher rates; an enrollment difference of 100 students was associated with a $1 \%$ difference in the odds of teachers departing. Notably, the school size effect was more pronounced for mathematics teachers, as evidenced by the consistently significant interaction between the mathematics indicator and school size. For mathematics teachers, an enrollment decrease of 100 students was associated with a 4 to $5 \%$ increase in the odds of teachers departing.

The question of particular interest here is: after controlling for the characteristics of teachers and schools, were the organizational conditions of schools associated with turnover? In each of the models shown, the introduction of the organizational variable improved the model likelihood statistic by a statistically significant amount; moreover, after controlling for the 
characteristics of teachers and schools, a number of conditions remained significantly associated with turnover.

Although the measure for top salaries (the highest annual salary on the school district's teacher salary scale) had a statistically significant negative bivariate relationship with turnover without controls, once other background factors were held constant as shown in model 1, the coefficient for highest salaries was no longer statistically significant (at a 90\% level of confidence) for mathematics and for non-mathematics/science teachers. However, for science teachers salaries seemed to matter more. A \$10,000 difference across two schools in their highest teacher salary offered was associated with a $16 \%$ difference (i.e., $\exp (-0.02)+(-0.16)=$ 0.84) in the odds of science teachers departing. The SASS data indicate that in 2003-04, the average starting salary in public schools for a teacher with a bachelor's degree and no experience was about $\$ 32,000$, and the average maximum salary (the measure used here) was about $\$ 61,000$.

As mentioned earlier, (except for salary) in our analyses we used two types of measures of organizational conditions: 1) school-level averages across the teachers in each school, and 2) teacher-level measures showing the extent to which individual teachers differed from others in their building. In our models, use of the former measures tells us whether particular school conditions on average are related to turnover; the latter measures tell us whether individuals who reported conditions differently than others in their schools, were also more or less likely to depart than others.

As shown in model 2, in schools with lower levels of student discipline problems, turnover rates were distinctly lower for both mathematics/science and other teachers. This is one of the stronger relationships we found. A 1-unit increase in average reported student discipline 
problems between two schools (on a 5 -unit scale) was associated with a $32 \%$ increase (i.e., $\exp (0.28)=1.32)$ in the odds of a teacher departing. Moreover, individual teachers who reported higher levels of student discipline problems than other teachers in their building were themselves more likely to have departed. But, notably the association of school-wide conditions was stronger, about twice the size, than that of individual perceptions.

As shown in model 3, in schools which provide better principal leadership and administrative support as reported by teachers, turnover rates were distinctly lower. A 1-unit difference between schools in average reported support (on a 4-unit scale) was associated with a $20 \%$ decrease in the odds of a teacher departing. Again, as with student discipline, individual teachers who reported more positive levels of leadership support than other teachers in their building were themselves less likely to depart, although that individual coefficient was again only about half the size of the school-level coefficient.

In schools where teachers reported that necessary materials, such as textbooks and supplies were available, turnover was lower for all teachers. In model 4, the individual and school-level associations were the same size. In other words, teachers who themselves had limited resources were more likely to depart, as were teachers in schools in which necessary resources were not generally available across the building.

As shown in model 5 schools with higher levels of school-wide faculty decision-making influence had lower levels of turnover. This is also one of the stronger relationships we found. A 1-unit increase in reported faculty influence between schools (on a 4-unit scale) was associated with a $23 \%$ decrease in the odds of a teacher departing. Moreover, whether individual teachers differed in their reports of faculty influence was not related to their turnover. Therefore, this may 
be entirely an organizational phenomenon reflecting differences in school-wide organizational conditions.

As shown in model 6, schools with higher average levels of individual teachers' classroom autonomy had lower levels of turnover. A 1-unit difference in reported teacher influence between schools (on a 4-unit scale) was associated with a 37\% difference in the odds of a teacher departing. This school-level association was nearly three times the size of the individual association of autonomy, suggesting a very large contextual relationship. Thus, the overall classroom autonomy held by teachers in the building had a larger relationship than an individual's own perceptions of their classroom autonomy. Even more noteworthy is that the turnover of mathematics teachers was even more strongly related to classroom autonomy. In fact, a 1-unit increase in average teacher autonomy between schools was associated with a 70\% decrease in the odds of a mathematics teacher departing (i.e., $\exp (-0.46)+(-0.75)=0.30$ ). This was by far the single largest relationship we found. On the other hand, the significant positive interaction coefficient for science teachers suggests that, unlike others, classroom autonomy had no relationship to the odds of turnover (i.e., $-.46+.47=0$ ).

We also examined the relationship with turnover of whether teachers participated in and found useful two types of PD: 1) that focused on student discipline and classroom management, and 2) that focused on the content of the subjects taught. School-wide utility of the former type of PD was associated with decreases in turnover for mathematics teachers only, but the relationship was large. A 1--unit increase in the school-average utility of PD focused on student discipline was associated with a 39\% reduction in the odds of turnover for mathematics teachers. We also found significant associations for the utility of PD focused on the content taught; however, those relations existed only at the individual teacher level, not at the organizational 
level. Teachers who found content-focused PD more useful had a 10\% lower odds of turnover. This relationship was even larger for mathematics teachers—-those who found content-focused PD more useful had 27\% lower odds of turnover.

We also estimated our same set of models for movers and leavers separately to explore differences in the predictors of each component of turnover. In most cases the direction and magnitude of the coefficient was similar to that found in the models analyzing the full sample in Table 7. For none of our eight measures of organizational characteristics were there statistically significant differences in their degree of association with leaving versus moving. In other words, organizational conditions associated with higher rates of teacher migration were similarly associated with higher rates of teacher attrition.

The separate models in Table 7 estimate the independent relationships to turnover of each organizational condition. However, as discussed in the Data/Methods section, the above organizational conditions do not exist in isolation; schools with higher levels of one were also likely to have higher levels of others. This is born out in Table 8 which estimates the relationships of all of the organizational conditions concurrently in a full model. The attenuation of the size of some of the coefficients when all of the variables are modeled simultaneously, making some statistically insignificant, confirms this confounding between related variables. However, the fact that the associations of some of the organizational conditions was not strong enough to be individually statistically significant in the full model does not mean they have no value as components in a collective set of school organizational conditions. To get a sense of the joint association with turnover of multiple organizational conditions we estimated predicted turnover rates by entering a range of values for the set of all organizational variables. 
Table 8: Logistic Regression Analysis of the Likelihood of Mathematics and Science Teacher Turnover

\begin{tabular}{|c|c|}
\hline & Full Model \\
\hline School N & 6,627 \\
\hline Teacher N & 34,375 \\
\hline Intercept & $-2.08^{* * *}$ \\
\hline \multicolumn{2}{|l|}{ Teacher Characteristics } \\
\hline Young & $0.71^{* * *}$ \\
\hline Old & $0.32^{* * *}$ \\
\hline Male & $0.17^{* *}$ \\
\hline Minority & -0.01 \\
\hline \multicolumn{2}{|l|}{ Teacher Field } \\
\hline Mathematics & $0.36^{\sim}$ \\
\hline Science & $-0.22^{\sim}$ \\
\hline \multicolumn{2}{|l|}{$\underline{\text { School Characteristics }}$} \\
\hline Rural & -0.10 \\
\hline Suburban & -0.04 \\
\hline Secondary & -0.02 \\
\hline School Size (in 100s) & -0.01 \\
\hline School Size (in 100s) x Mathematics & $-0.05^{* *}$ \\
\hline Poverty Enrollment (in10s) & 0.02 \\
\hline \multicolumn{2}{|l|}{ Organizational Characteristics/Conditions } \\
\hline Highest Salary (in 10,000s) & -0.03 \\
\hline Science x Highest Salary & $-0.15^{\sim}$ \\
\hline \multicolumn{2}{|l|}{ Student Discipline Problems } \\
\hline School-Level & $0.22^{*}$ \\
\hline Teacher-Level & 0.07 \\
\hline \multicolumn{2}{|l|}{ School Leadership Support } \\
\hline School-Level & -0.10 \\
\hline Teacher-Level & $-0.12^{\sim}$ \\
\hline \multicolumn{2}{|l|}{ School Resources } \\
\hline School-Level & -0.01 \\
\hline Teacher-Level & $-0.07^{\sim}$ \\
\hline \multicolumn{2}{|l|}{ Faculty Influence } \\
\hline School-Level & -0.07 \\
\hline Teacher-Level & $-0.15^{*}$ \\
\hline \multicolumn{2}{|l|}{ Teacher Autonomy } \\
\hline School-Level & $-0.36^{* *}$ \\
\hline School-Level x Mathematics & $-0.86^{*}$ \\
\hline School-Level x Science & $0.51^{\sim}$ \\
\hline Teacher-Level & $-0.14^{*}$ \\
\hline \multicolumn{2}{|l|}{ Discipline-Focused Prof. Dev. } \\
\hline School-Level & 0.08 \\
\hline School-Level x Mathematics & $-0.56^{* *}$ \\
\hline Teacher-Level & 0.01 \\
\hline \multicolumn{2}{|l|}{ Content-Focused Prof. Dev. } \\
\hline School-Level & -0.03 \\
\hline Teacher-Level & $-0.25^{*}$ \\
\hline Teacher-Level x Mathematics & $-0.10^{* * *}$ \\
\hline
\end{tabular}

Note. ${ }^{\sim} \mathrm{p}<.10,{ }^{*} \mathrm{p}<.05,{ }^{* *} \mathrm{p}<.01,{ }^{* * *} \mathrm{p}<.001$ 
Holding the control variables constant at the sample mean, we set the eight organizational condition variables to values corresponding to the $10^{\text {th }}$ percentile, the $25^{\text {th }}$ percentile, the mean, the $75^{\text {th }}$ percentile, and the $90^{\text {th }}$ percentile for the sample. This allowed us to predict the turnover rates of mathematics and science teachers for a range of hypothetical schools, beginning with those that have the worst organizational conditions (i.e., at the $10^{\text {th }}$ percentile on each of the eight organizational measures) and concluding with those that have the best organizational conditions (i.e., at the $90^{\text {th }}$ percentile on each of organizational measures). Results from this analysis are depicted in Figure 3 and reveal a clear collective relationship between organizational conditions and turnover. This relationship is remarkably strong for mathematics teachers, whose predicted annual turnover rates are only $2.8 \%$ in the schools with the best organizational conditions versus nearly $42 \%$ in schools with the worst organizational conditions. In science the relationship is not as strong, but is still quite large, ranging from $6.9 \%$ in the best schools to $17.2 \%$ in the worst schools.

It is also worth noting that once all of the organizational conditions are included (in the full model) the coefficients for school poverty and rural schools decrease and become statistically insignificant— suggesting that worse organizational conditions account for some of the higher turnover in poor and urban schools.

When other factors are controlled, the strongest organizational predictors for mathematics teachers were the degree of individual classroom autonomy held by teachers, the provision of useful content-focused PD, useful PD concerning student discipline and classroom management, and the degree of student discipline problems. In contrast, for science teachers, the strongest factors were the maximum salary offered by school districts, the degree of student discipline problems in schools, and useful content-focused PD. 


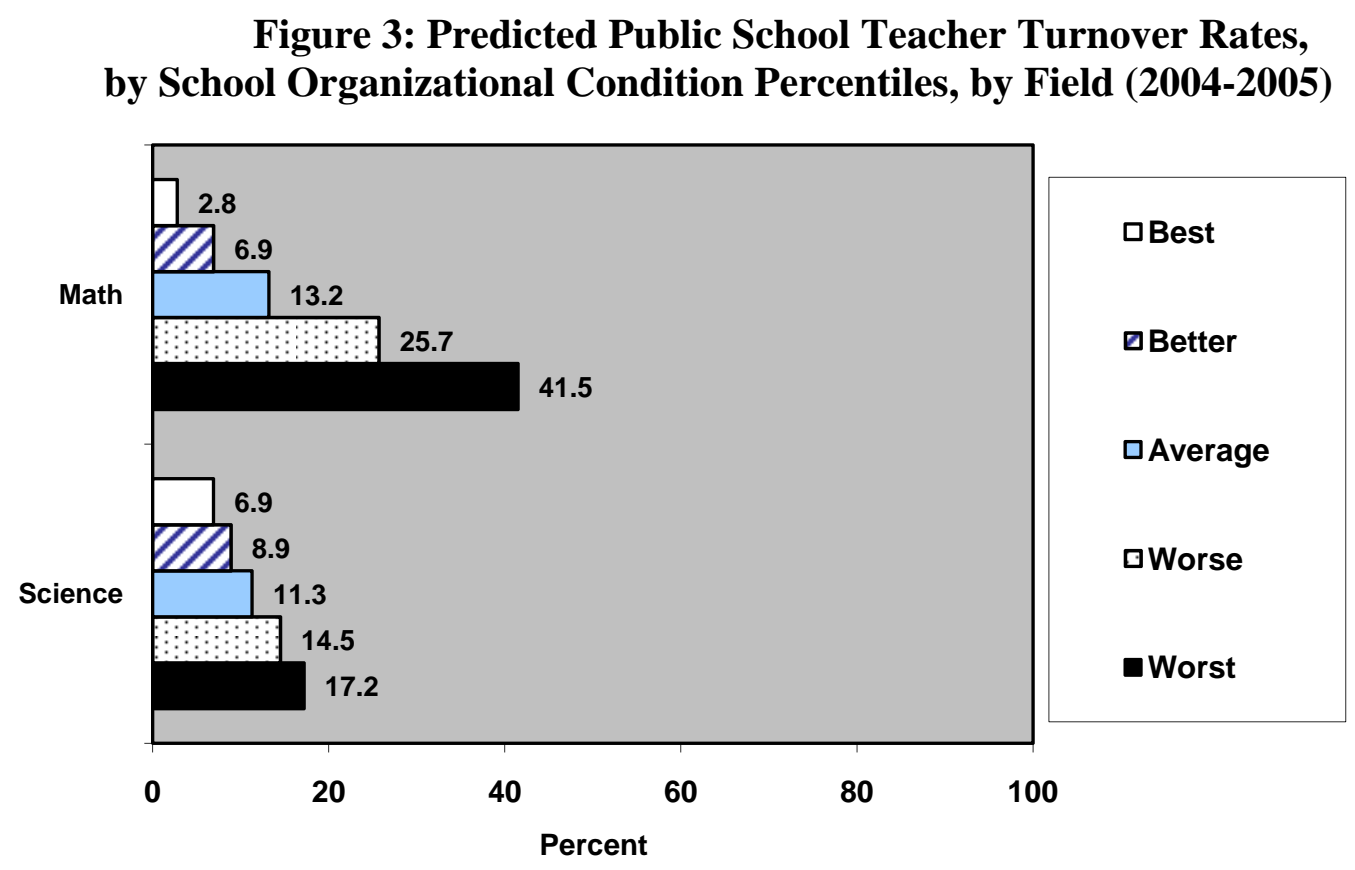

\section{Conclusions and Implications}

Some turnover of mathematics and science teachers is, of course, normal, inevitable, and beneficial. For individuals, departures leading to better jobs, either in teaching or not, can be a source of upward mobility. For schools, departures of low-performing employees can enhance organizational outcomes. For the educational system, teacher outflows, such as cross-school migration, temporary attrition, or those leaving classroom teaching for other education-related jobs, do not represent a net or permanent loss of human capital to the education system as a whole and can be beneficial to the system.

However, from an organizational level of analysis and from the viewpoint of those managing schools, none of these types of departures are cost free, whether permanent, to other schools, or to other education jobs. All have the same effect; they typically result in a decrease in classroom mathematics and science instructional staff in that particular organization, who usually must be replaced. As mentioned earlier, in a companion study (Ingersoll and Perda 
2010a), we have documented that mathematics and science teacher turnover is a major factor behind the mathematics and science teacher shortage. The data show that over the past two decades the new supply of qualified mathematics and science teachers has more than kept pace both with increases in student enrollments and with increases in teacher retirements. Indeed, the number of qualified math and science teachers has increased at far faster rate than other teachers. Nevertheless, a significant minority of the school population has continued to report serious problems filling their math and science teaching openings. An important source of these problems is revealed when we factor in preretirement losses of teachers—a figure that is many times larger than losses due to retirement—and a primary factor behind the need for new hires.

In this present report, we have followed up by more closely examining the magnitude, destinations and determinants of mathematics and science teacher turnover from public schools. It is useful to summarize our main findings, below, by examining and comparing the actual numbers involved.

\section{Magnitude}

Qualified math and science teachers represent about 12 percent of the entire k-12th grade teaching force. Between the 2003-04 and 2004-05 school years about 51,400 qualified mathematics and science teachers, or about $14 \%$ of the mathematics and science public school teaching force, departed from their schools. This rate represented an overall increase since the late 1980s. But contrary to a number of studies, (e.g., Grissmer \& Kirby, 1992; Murnane et al., 1991; Rumberger, 1987; Weiss \& Boyd 1990; Henke et al. 2001; Ingersoll 2006), the data show that mathematics and science teachers do not have higher rates of turnover than other teachers. The turnover of mathematics and science teachers has fluctuated up and down, but overall, has 
not been consistently different than that of non-mathematics/science teachers. Indeed, in 200405 science teachers had significantly lower turnover than others.

Either way, these outflows are large; just before, during, and just after the 2003-04 school year, over one quarter of the entire mathematics/science public school teaching force was in job transition—into, between, or out of schools. Focusing on overall rates of turnover, however, masks an important part of the story—math and science teacher turnover is not equally distributed. The data show differences across states and school districts, but by far the largest variations in overall teacher turnover by location are those between different schools, even within the same district. Teacher turnover is highly concentrated in a small portion of the school population. The data show that $45 \%$ of all public school teacher turnover, after the 2004-05 year, took place in just one quarter of the population of public schools.

\section{Destinations}

Mathematics and science teachers departed for a wide variety of destinations. Of those 51,400 who departed, just over half left teaching altogether and just under half moved to other schools. Prior studies using data from Texas (Hanushek \& Rifkin 2004) and from New York state (Lankford et al. 2002) to examine teacher cross-school and cross-district migration concluded that the movement of teachers from high-need urban schools to lower-need suburban schools resembles an asymmetric "brain drain," and exacerbates an unequal distribution of qualified teachers across demographically different settings.

However, our analyses of national data show that the majority of teachers who moved between schools tended to not move to demographically different school settings. Indeed, movers were most likely to migrate to demographically similar types of schools. But, because of the far higher overall migration rates of math and science teachers from high-poverty, high- 
minority, and urban public schools, the end result was an annual asymmetric reshuffling of significant numbers of math and science teachers from poor to not poor schools, from high minority to low minority schools, and from urban to suburban schools.

Of those 51,400 departures, about 4,500 math and science teachers left teaching to work in jobs outside of education. A commonly held view in both the research and education policy realms (e.g., Murnane et al., 1991; Rumberger, 1987; National Research Council 2002; National Academy of Sciences 2007), is that teachers with a mathematics and science background are more likely to have alternative career options in the private sector than others. But, surprisingly, our data show that qualified mathematics and science teachers were no more likely than other teachers to leave to take non-education jobs, such as in technological fields, or to be working for private business or industry. In contrast, a far larger number-10,200_left for non-teaching jobs within the education sector, such as school administration or curriculum development.

It is widely believed that teacher retirement is a major factor behind teacher staffing problems (e.g., National Commission on Teaching and America’s Future 1996, 1997; U.S. Department of Education, 2002). However, in 2004-05 only about 7,000 math and science teachers reported retirement was a very important reason for their decision to leave teaching. In contrast, about 34,400 math and science teachers indicated the main motive behind their moves or leaves was dissatisfaction with teaching, or with their schools, or to move to a better fitting or better paying teaching job, or to seek other career opportunities in education, or to pursue a career out of the education sector entirely.

\section{Determinants}

Our analyses focused on a number of widely studied organizational characteristics and conditions, considered important to effective schools: the maximum potential salary offered by 
school districts; the degree of student discipline problems in buildings; the effectiveness of the school leadership and administrative support; the availability of necessary classroom resources; the extent of school-wide decision-making influence collectively held by the faculty; the degree of classroom autonomy held by individual teachers; the usefulness of PD activities focused on student discipline/classroom management, and the usefulness of PD in subject-area content.

As expected, we found that schools greatly varied in these organizational conditions. We also found that all were statistically related to teacher turnover. But, there were some interesting differences for math and science.

For math teachers among the strongest factors were the degree of student discipline problems in the school, and the extent to which individuals received useful content-focused PD. However, by far the strongest predictor for mathematics teachers was the degree of individual classroom autonomy held by teachers; in contrast for science teachers classroom autonomy was a non-factor. Perhaps in an era of accountability, by 2004, highly tested fields such as math may have seen a reduction in classroom discretion, less true for other fields such as scienceresulting in disproportionate dissatisfaction for math teachers. This is an issue worth further investigation and has implications for the successful implementation of accountability reforms. Another strong factor for math teachers - the usefulness of PD concerning student discipline and classroom management—also had no relationship to science teachers' likelihood of departing. Interestingly, for math teachers school size also was important; the smaller the school, the more likely math teachers were to depart. This finding raises interesting questions for research on school size, which generally finds smaller schools to be advantageous, and for the "small is beautiful" movement that has been popular among reformers and policymakers (for a review see, 
Leithwood \& Jantzi 2009). These data suggest, however, that one possible disadvantage of smaller schools, often overlooked in the debates over the relative merits of small and large, is their difficulty retaining qualified math teachers.

For science teachers the strongest factor was the maximum potential salary offered by school districts; in contrast, for math teachers this was, surprisingly, a non-factor. In other words, these data suggest that math teachers' decisions to stay or depart are less related to potential salaries than to other school organizational conditions; while science teachers’ decisions are more strongly related to their potential future salary in a district. This is another finding worth further investigation and has implications for differential pay programs. But, there were also other factors strongly related to the turnover of science teachers, such as the degree of student discipline problems in the school, and the extent to which individuals received useful content-focused PD. This is important because, given the large size of the teaching force, salary increases are expensive. For instance, raising the annual salary of all qualified math and science teachers by only $\$ 1000$ each would cost almost one half billion dollars per year.

Most of these relations appear to be partly or entirely the result of organizational-level phenomena. That is, regardless of an individual's own views of conditions in schools, positive school-wide conditions were related to an individual's likelihood of turnover, especially for student discipline, leadership, autonomy, influence and discipline PD. Moreover, the relationship to teacher turnover of these organizational conditions increased cumulatively. These conditions do not exist in isolation from one another. Schools tend to have positive or negative levels of more than one condition simultaneously. Schools with positive levels of progressively more of these conditions had progressively lower turnover of math and science teachers. As a result, collectively, these conditions had a very large relationship with turnover. 
While numerous studies have documented that teacher turnover is higher in high-poverty, high-minority and urban public schools, there has been little research on why this is so (for comprehensive reviews, see, e.g., Guarino et al., 2006; Borman \& Dowling, 2008). Our data suggest that organizational conditions account for the relationship between school poverty, school urbanicity and teacher turnover. In other words, the high rates of math and science teacher turnover in high-poverty, urban, public schools do not appear to be a matter of student and school demographic characteristics per se, but appear to be a matter of worse organizational conditions in such settings. Similarly, as mentioned earlier, the data suggest that math and science teachers who migrate from one school to another are not seeking to move to demographically opposite settings. They are migrating out of settings with worse organizational conditions. These findings provide support for our theoretical perspective that school organization, management, and leadership matter and have large implications for reform initiatives concerned with addressing inequities in the distribution of qualified teachers—a point to which we return below.

While our analysis has focused on the identifying the organizational characteristics and conditions of school districts and schools that predict math and science teacher turnover (depicted on the left side of Figure 1), we did not address a related and important question — what state, district and school factors predict these positive organizational characteristics and conditions of schools? In short, how do school system leaders, especially in disadvantaged settings, create these conditions? This is another issue warranting further research.

\section{Policy Implications}

What are the implications of these results for reform? As noted in the beginning of this report, increased teacher production and recruitment have long been the dominant strategies to 
address mathematics and science teacher staffing problems. Nothing in this research suggests that bringing new qualified mathematics and science candidates into teaching is not a worthwhile step. But the data indicate that new teacher production and recruitment strategies, alone, do not directly address a major root source of mathematics and science teacher staffing problemsturnover. To illustrate, President Bush pledged in his 2006 State of the Union speech to recruit 30,000 new mathematics and science teachers across the nation. Comparison with our above figures is revealing: after the end of the prior school year (2004-05), about 26,400 mathematics and science public school teachers left teaching. Of these, 7,000 left to retire, another 14,000 indicated they left to pursue another job or career, or because of job dissatisfaction. Improving the retention of those mathematics and science teachers brought into teaching by recruitment initiatives could prevent the loss of this investment, and also help to lessen the ongoing need for creating new similar recruitment initiatives. All this suggests the efficacy of developing teacher recruitment and retention initiatives together.

Again, school-to-school differences are important. Disadvantaged schools, in particular, have among the highest rates of math and science moving and leaving — with predictable negative consequences for the educational, and ultimately, occupational achievement gap. However, investigating the role of school management and leadership in the problems of the educational system, especially for disadvantaged communities, is a highly contentious subject. Some hold that incompetent and corrupt school managers are a major factor in the plight of lowincome, inner-city public schools. Others forcefully respond that this viewpoint unfairly places responsibility for the problems of low-performing schools on the victims of these same problems and unfairly shifts responsibility away from systemic inequities in funding and resources (for discussion of this debate, see, e.g., Kozol, 1991). 
This study’s organizational perspective shifts attention away from this polarized debate, does not blame either managers or demography, but focuses on discovering which policyamenable aspects of schools as organizations - their practices, policies, characteristics, and conditions - are related to their ability to retain qualified math and science teachers. The data suggest that poor urban schools with improved organizational conditions will be far more able to do so. To be sure, the data do not suggest that altering any of the organizational conditions we examined would be easy. However, unlike reforms such as teacher salary increases and classsize reduction, changing many of the above organizational conditions appear to be less costly financially — an important consideration, especially in low-income settings. 


\section{References}

Abelson, M.A., \& Baysinger, B.D. (1984). Optimal and dysfunctional turnover: Toward an organizational level model. The Academy of Management Review, 9(2), 331-341.

Alliance for Excellent Education. (2005). Teacher attrition: A costly loss to the nation and to the states. Washington, DC: Author.

Barnes, G., Crowe, E., \& Schaefer, B. (2007). The cost of teacher turnover in five school districts. Washington, DC: National Commission on Teaching and America's Future.

Becker, G.S. (1993) Human Capital: A Theoretical and Empirical Analysis, with Special Reference to Education (3rd Edition). University of Chicago Press, Chicago.

Behrstock, E. (2009). Teacher shortage in England and Illinois: A comparative history. Unpublished dissertation. Oxford University.

Borman, G.D., \& Dowling, N.M. (2008). Teacher attrition and retention: A meta-analytic and narrative review of the research. Review of Educational Research, 78, 367-409.

Boyd, D., Grossman, P., Lankford, H., Loeb, S., \& Wyckoff, J. (2007). Who leaves? Teacher attrition and student achievement. Albany, NY: Teacher Policy Research Center, State University of New York-Albany.

Bryk, A., Lee, V., \& Smith, J. (1990). High school organization and its effects on teachers and students: An interpretive summary of the research. In W. H. Clune \& J. F. Witte (Eds.), Choice and control in American education, Volume 1: The theory of choice and control in education. New York: Falmer Press.

Bryk, A., Lee, V., \& Holland, P. (1993). Catholic schools and the common good. Cambridge, MA: Harvard University Press.

Burstein, L. (1980). Issues in the aggregation of data. Review of Research in Education, 8, 158236.

Chandler, K., Luekens, M., Lyter, D., \& Fox, E. (2004). Teacher attrition and mobility: Results from the teacher follow-up survey, 2000-01. Washington, DC: National Center for Education Statistics.

Chubb, J. E., \& Moe, T. (1990). Politics, markets and America's schools. Washington, DC: Brookings Institute.

Clotfelter, C.T., Ladd, H.F., \& Vigdor, J.L. (2006, Fall). Teacher-student matching and the assessment of teacher effectiveness. Journal of Human Resources, 41(4), 778-820.

Coleman, J., \& Hoffer, T. (1987). Public and private schools: The impact of communities. New York: Basic.

Committee on Evaluation of Teacher Certification by the National Board for Professional Teaching Standards. (2008). Assessing accomplished teaching: Advanced-level certification programs. Washington, DC: National Research Council of the National Academies of Science.

Cotton, J.L., \& Tuttle, J.M. (1986). The academy of management review of employee turnover:

A meta-analysis and review with implications for research. Academy of Management Review, 11(1), 55- 70.

Dalton, D.R., Todor, W.D., \& Krackhardt, D.M. (1982, Jan.) Turnover overstated: The functional taxonomy. The Academy of Management Review, 7(1), 117-123.

Darling-Hammond, L. (1984). Beyond the commission reports: The coming crisis in teaching. Santa Monica, CA: RAND.

Darling-Hammond, L. (2007). Recruiting and retaining teachers: What matters most 
and what can government do? Washington, D.C.: The Forum for Education and Democracy.

Feistritzer, E. (1997). Alternative teacher certification: A state-by-state analysis (1997). Washington, DC: National Center for Education Information.

Fowler, R.C. (2008, Jan.). The heralded rise and neglected fall of the Massachusetts signing bonus. Phi Delta Kappan, 89(5), 380-85.

Goldhaber, D., Gross, B., \& Player, D. (2007). Are public schools really losing their best teachers? Washington, DC: National Center for Analysis of Longitudinal Data in Educational Research, Urban Institute.

Goodlad, J. (1984). A place called school: Prospects for the future. St Louis: McGraw-Hill.

Grant, G. (1988). The world we created at Hamilton High. Cambridge, MA: Harvard University Press.

Griffeth, R.W., Hom, P.W. \& Gaertner, S. (2000). A meta-analysis of antecedents and correlates of employee turnover: Update, moderator tests, and research implications for the next millennium. Journal of Management, 26(3), 463-488.

Grissmer, D., \& Kirby, S. (1992). Patterns of attrition among Indiana teachers, 1965-1987. Santa Monica, CA: RAND.

Guarino, C, Santibanez, L, Daley, G., \& Brewer, D. (2004). A review of the research literature on teacher recruitment and retention. Santa Monica, CA: RAND Corporation. (http://www.rand.org/publications/TR/TR164/)

Guarino, C., Santibanez, L., \& Daley, G. (2006). Teacher recruitment and retention: A review of the recent empirical literature. Review of Educational Research, 76(1), 173-208.

Halaby, C., \& Weakliem, D. (1989). Worker control and attachment to the firm. American Journal of Sociology, 95, 549-591.

Hanushek, E., Kain, J. \& Rivkin, S. (2004). Revolving door. Education Next, 77(1), 77-82.

Harris, D. (2009). Toward policy-relevant benchmarks for interpreting effect sizes: Combining effects with costs. Educational Evaluation and Policy Analysis, 31(1), 3-29.

Henke, R., Zahn, L \& Carroll, D. (2001). Attrition of new teachers among recent college graduates. Washington, DC: National Center for Education Statistics.

Hirsch, E., Koppich, J., \& Knapp, M. (2001). Revisiting what states are doing to improve the quality of teaching: An update on patterns and trends. Seattle, WA: Center for the Study of Teaching and Policy, University of Washington.

Hirschman, A. (1970). Exit, voice and loyalty. Cambridge: Harvard University Press.

Hom, P., \& Griffeth, R. (1995). Employee turnover. Cincinnati, OH: South-Western.

Hussar, W. (1998). Predicting the need for newly hired teachers in the United States to 2008-09.

Washington, DC: National Center for Education Statistics.

Ingersoll, R. (1999). The problem of underqualified teachers in American secondary schools.

Educational Researcher, 28(2), 26-37.

Ingersoll, R. (2001). Teacher turnover and teacher shortages: An organizational analysis. American Educational Research Journal, 38(3), 499-534.

Ingersoll, R. (2006). Understanding supply and demand among mathematics and science teachers. In J. Rhoton and P. Shane (Eds.), Teaching Science in the 21st Century (pp.197211). Arlington, VA: National Science Teachers Association.

Ingersoll, R., \& Perda, D. (2010a). Is the supply of mathematics and science teachers sufficient? American Educational Research Journal, 47(3), 563-595.

Ingersoll, R., \& Perda, D. (2010b). How high is teacher turnover and is it a problem? 
Consortium for Policy Research in Education, University of Pennsylvania.

Iversen, G. R. (1991). Contextual Analysis. Newbury Park, CA: Sage.

Johnson, S.M., Berg, J., \& Donaldson, M. (2005). Who stays in teaching and why: A review of the literature on teacher retention. Cambridge, MA: Harvard Graduate School of Education. (http://assets.aarp.org/www.aarp.org_/articles/NRTA/Harvard_report.pdf)

Jovanovic, B. (1979a). Job matching and the theory of turnover. Journal of Political Economy, 87(5), 972-90.

Jovanovic, B. (1979b). Firm-specific capital and turnover. Journal of Political Economy, 87(6), 1246-1260.

Jovanovic, B., \& Mincer, J.(1981). Labor mobility and wages. In S. Rosen (Ed.), Studies in labor markets, NBER Conference Report. University of Chicago Press, Chicago.

Kalleberg, A., \& Mastekaasa, A. (1998). Organizational size, layoffs and quits in Norway. Social Forces, 76, 1243-1273.

Keesler, V. (2010). Estimating cause: Teacher turnover and school effectiveness in Michigan. Paper presented at the annual conference of the Society for Research on Educational Effectiveness. Washington, DC.

Kimmitt. R. (2007, Jan.23). Why job churn is good. Washington Post (P.A17).

Kreft, G. G., De Leeuw, J., \& Aiken, L. S. (1995). The effects of different forms of centering in hierarchical linear models. Multivariate Behavioral Research, 30, 1-21.

Krieg, J.M. (2004). Teacher quality and attrition. Economics of Education Review, 25, 13-27.

Lankford, H., Loeb, S., \& Wyckoff, J. (2002). Teacher sorting and the plight of urban schools: A descriptive analysis. Educational Evaluation and Policy Analysis, 24(1), 37-62.

Leithwood, K. \& Jantzi, D. (2009). A review of empirical evidence about school size effects: A policy perspective. Review of Educational Research, 79(1), 464-490.

Levy, A.J., Ellis, P., Joy, L., Jablonski, E., \& Karelitz, T.M. (2010, April). The causes and costs of turnover for science and other teachers. Paper presented at the 2010 American Educational Research Association Annual Meeting, Denver, CO.

Liu, E., Rosenstein, J., Swann, A., \& Khalil, D. (2008). When districts encounter teacher shortages? The challenges of recruiting and retaining math teachers in urban districts. Leadership and Policy in Schools, 7(3), 296-323.

Lortie, D. (1975). School teacher. Chicago: University of Chicago Press.

Meier, K.J., \& Hicklin, A. (2007). Employee turnover and organizational performance: testing a hypothesis from classical public administration. Journal or Public Administration Research and Theory, 18, 573-590.

Milanowski, A., \& Odden, A. (2007). A new approach to the cost of teacher turnover. Seattle, WA: Center on Reinventing Public Education.

Mobley, W. (1982). Employee turnover: Causes, consequences and control. Reading, MA: Addison-Wesley.

Mueller, C., \& Price, J. (1990). Economic, psychological and sociological determinants of voluntary turnover. Journal of Behavioral Economics, 19, 321-335.

Murnane, R., Singer, J., Willett, J., Kemple, J., \& Olsen, R. (1991). Who will teach? Policies that matter. Cambridge, MA: Harvard University Press.

National Academy of Sciences. (1987). Toward understanding teacher supply and demand. Washington, DC: National Academies Press.

National Academy of Sciences. (2007). Rising above the gathering storm. Washington, DC: National Academies Press. 
National Commission on Excellence in Education. (1983). A nation at risk: The imperative for educational reform. Washington, DC: Government Printing Office.

National Commission on Mathematics and Science Teaching for the 21st Century (the Glenn Commission). (2000). Before it's too late. Washington, DC: Government Printing Office.

National Commission on Teaching and America's Future. (1996). What matters most: Teaching for America's future. New York: NCTAF.

National Commission on Teaching and America's Future. (1997). Doing what matters most: Investing in quality teaching. New York: National Commission on Teaching and America's Future.

National Center for Education Statistics. (2005). Schools and staffing survey (SASS) and teacher follow-up survey (TFS). Data File. Washington, DC: U.S. Department of Education. Available from http://nces.ed.gov/surveys/SASS

National Research Council. (2002). Learning and understanding: Improving advanced study of mathematics and science in U.S. schools. Washington, DC: National Academies Press.

Oi, W.Y. (1962). Labor as a quasi-fixed factor. The Journal of Political Economy, 70(6), 538555.

Price, J. (1977). The study of turnover. Ames, IA: Iowa State University Press.

Price, J. (1989). The impact of turnover on the organization. Work and Occupations, (16), 461473.

Quartz, K., Thomas, A., Anderson, L., Masyn, K., Lyons, K., \& Olsen, B. (2008). Careers in motion: A longitudinal study of role changing patterns among urban educators. Teachers College Record, 110.

Raudenbush S. W., \& Bryk, A. S. (2002). Hierarchical Linear Models (2nd Ed.). Newbury Park, CA: Sage.

Rice, J., Roellke, C., Sparks, D., \& Kolbe, T. (2008). Piecing together the teacher policy landscape: A policy-problem typology. Teachers College Record. Available at http://www.tcrecord.org/Content.asp?ContentId=15223

Rumberger, R. W. (1987). The impact of salary differentials on teacher shortages and turnover: The case of mathematics and science teachers. Economics of Education Review, 6(4): 389-399.

Siebert, S.W., \& Zubanov, N. (2009). Searching for the optimal level of employee turnover: A study of a large U.K. retail organization. Academy of Management Journal, 52(2), 294-313.

Smylie, M. A., \& Wenzel, S. A. (2003). The Chicago Annenberg Challenge: Successes, failures, and lessons for the future (Final technical report of the Chicago Annenberg Research Project). Chicago: Consortium on Chicago School Research, University of Chicago.

Sullivan, S.E. (1999). The changing nature of careers: A review and research agenda. Journal of Management, 25, 457.

Texas Center for Educational Research. (2000). The cost of teacher turnover. Austin, TX: Texas State Board for Educator Certification.

Theobald, N. (1990). An examination of the influence of personal, professional and school district characteristics on public school teacher retention. Economics of Education Review, 9, 241-250.

Tyack. D. (1974). The one best system. Cambridge, MA: Harvard University Press.

U.S. Bureau of the Census. (2008). The statistical abstract (137th ed.). Washington, DC: U.S. Department of Commerce. 
U.S. Department of Education. 2002. Meeting the highly qualified teachers challenge: The secretary's annual report on teacher quality. Washington, DC: Author.

Villar, A., \& Strong, M. (2007). Is mentoring worth the money? A benefit-cost analysis and fiveyear rate of return of a comprehensive mentoring program for beginning teachers. ERS Spectrum, 25(3), 1-17.

Weiss, I. R., \& Boyd, S. E. (1990). Where are they now? A follow-up study of the 1985-86 science and mathematics teaching force. Chapel Hill, NC: Horizon Research.

Willms, J.D. (1986). Social class segregation and its relationship to pupils' examination results in Scotland. American Sociological Review, 51(2), 224-241.

Zumwalt, K., \& Craig, E. (2005). Teacher characteristics: Research on the demographic profile; Teacher characteristics: Research on the indicators of quality. In Studying teacher education: The report of the AERA panel on research and teacher education. Rahwah, NJ: Taylor \& Francis. 


\section{Endnotes}

i This preliminary Teacher Status variable has some error in distinguishing between migration (movers) and attrition (leavers). Essentially, school principals tend to over-report the number of leavers because teachers who quit their jobs often do not inform their previous schools that they have moved to another school. However, this measure is quite accurate in accurately identifying who is and isn't still working at the original school. By comparing individual teacher's values for the Teacher Status variable from SASS with confirmed final turnover from the TFS, we found the Teacher Status variable was about 93\% accurate in distinguishing teachers who had departed from those who had not.

More specifically, the Teacher Status variable from the SASS accurately identified $90 \%$ of confirmed leavers (i.e., 2,385 out of 2,650) as having left the teaching occupation. However, the Teacher Status variable classified 29\% of confirmed movers (i.e., 559 out of 1,911) as having left the teaching occupation, and an additional 1\% of confirmed movers (i.e., 18 out of 1,911) as stayers. When no distinction is made between movers and leavers, the Teacher Status variable was $92 \%$ sensitive (i.e., 4,471 out of 4,886 teachers identified as departing did, in fact, move from or leave their teaching jobs), and Teacher Status was $96 \%$ specific (i.e., 2,442 out of 2,532 teachers identified as not turning over did, in fact, stay in their teaching jobs). This translates to an overall accuracy rate of $93 \%$ (i.e., 6,913 out of 7,418).

In our merger of the SASS and TFS measures, we corrected the Teacher Status measure using TFS data making the former approximately $96 \%$ accurate. Applying the sensitivity and specificity rates above to the uncorrected ATTRIT data (i.e., 40,563 stayers and 3,064 movers/leavers) and assuming 100\% accuracy for those teachers included in the TFS data (i.e., 2,864 stayers and 4,565 movers/leavers), we end up with an overall accuracy rate of $96 \%$ (i.e., $[(40,563 \times .96)+(3,064 \times .92)+(2,864 \times 1.00)+(4,565 \times 1.00)] / 51,056=0.96)$.

ii The proportion of a school's student population that is minority is also related to teacher turnover. However, minority enrollment is highly intercorrelated and confounded with poverty enrollment and, since the latter had a stronger relationship to turnover, we did not include the former in our regression analyses.

iii Especially with an aging teaching workforce, it can be unclear if differences in average salary levels are due to real differences in the compensation offered to comparable teachers at different schools or are due to differences in the experience and education levels of the teachers employed. That is, a school with older teachers may appear to offer better salaries, when, in fact, they do not. A more accurate method of comparison across schools is to compare the normal salaries paid by schools to teachers at common points in their careers. Teacher salary levels are often standardized by school districts according to a uniform salary schedule, based on the education levels and years of experience of the teachers. In this analysis we tested two salary schedule measures - each based on a different point on school salary schedules: 1) the normal yearly base salary for a teacher with 10 years of experience and a masters degree; and 2) the normal yearly base salary for a teacher at the highest possible step on salary schedule. The latter measure had a slightly stronger association with turnover than the former, and it also had relatively fewer missing data; hence, it is used in this report. This measure represents the organizational financial 
rewards teachers can look forward to at an advanced point in their careers if they stay in their particular schools and, hence, we expect could affect their decisions to depart or stay.

This measure also may have limitations. Some might argue that school salary schedules do not accurately capture the effect of salary on rates of teacher turnover because candidates can obtain this information in deciding whether to accept a particular teaching job. From this viewpoint, since public school teachers are compensated according to published salary schedules that change only infrequently, new entrants can predict with almost complete certainty how much they will be paid in each year in the future. Hence, if a teacher did accept a job, it suggests that they are satisfied with their school's salary levels and, hence, most likely low salaries would not be a factor in future turnover.

On the other hand, sometimes teachers may, of course, accept jobs with salaries below what they would prefer and then move in a few years when a better paying job opens up. Goodlad (1984) and others have argued that, while money is not a major factor in teachers' choice of a job, it is a major factor in their decision to move or leave teaching. In this view, beginning teachers are primarily motivated by non-pecuniary and intrinsic values, but if these kinds of expectations are frustrated, salaries can become a source of considerable dissatisfaction. Hence from this viewpoint, salary schedules would be related to turnover precisely because they allow teachers to predict how much they will be paid in the future. This analysis does not presume the validity of either view, but simply tests whether differences in advanced salaries among schools are related to turnover.

iv Using a 4-level logistic HLM model, estimated via MLwiN 2.20, we partitioned the variance in teacher turnover in the 03-04 SASS. Of the total variance in annual turnover, $77 \%$ was among schools, 16\% was among districts, and 7\% was among states.

v For further detail concerning our methods of aggregation, see Ingersoll and Perda 2010b.

${ }^{\text {vi }}$ For an insightful analysis of the flows of job shifting within education, see Quartz, et al. 2008.

vii To create high, middle and low poverty and minority categories, we divided the TFS sample of teacher movers into thirdtiles. Low poverty schools are those with 29 percent or less lowincome students; high poverty are those with 57 percent or more. Low minority schools are those with 22 percent or less minority students; high minority are those with 69 percent or more.

viii We exponentiated the coefficients from logistic regression models to produce odds ratios reflecting the relative change in odds associated with a one-unit increase in the predictor variable. For interactions, we calculated odds-ratios by adding coefficients from the main effect and the interaction term for a variable and then exponentiating. 


\section{Nondiscrimination Statement}

The University of Pennsylvania values diversity and seeks talented students, faculty, and staff from diverse backgrounds. The University of Pennsylvania does not discriminate on the basis of race, sex, sexual orientation, religion, color, national, or ethnic origin, age, disability, or status as a Vietnam Era Veteran or disabled veteran in the administration of educational policies, programs or activities; admissions policies, scholarships or loan awards; athletic, or University administered programs or employment.

Questions or complaints regarding this policy should be directed to Executive Director, Office of Affirmative Action, 1133 Blockley Hall, Philadelphia, PA 19104-6021 or (215) 898-6993 (Voice) or (215) 898-7803 (TDD). 